\title{
Los señoríos de los Manrique en la baja Edad Media
}

\author{
Rosa M Montero TEJada
}

\section{INTRODUCCIÓN}

El presente trabajo pretende hacer una descripción de los principales señoríos de los Manrique en el sigio XV, aunque sin entrar en un análisis profundo, pues carecemos de la documentación adecuada para tal fin. Los Manrique, como es bien sabido, fueron uno de los linajes de más destacado protagonismo político y social del siglo XV castellano. Presumían de la antigüedad de su estirpe, hacian gala y ostentación pública de ello entre sus iguales -incluso parece que gozaron del reconocimiento de sus contemporáneos-, y fueron testigo y parte de los principales acontecimientos de su época. La lenta pero firme ascensión política que habia iniciado el linaje desde mediados del siglo XIV le habia permitido consolidar las antiguas posesiones solariegas de la familia, y al mismo tiempo adquirir nuevos señorios gracias a las sustanciosas donaciones regias, especialmente de Enrique II y Juan I. La debilidad biológica del linaje, que a lo largo del siglo XIV fue víctima de la prematura mortalidad y de la escasa fertilidad de sus miembros, desapareció con el nacimiento de la nueva centuria, y la estirpe creció vertiginosamente dando lugar a la aparición de diversas ramas familiares que tuvieron primero como base económica primordial los bienes heredados de sus padres y antecesores, y después sus propias adquisiciones señoriales, como iremos viendo en las próximas páginas.

\section{LOS GRANDES SEÑORIOS}

1. El señorio de los Condes de Treviño y Duques de Nájera

a) El origen del señorio: la herencia del Adelantado de León Pedro Manrique

El punto de partida del señorío de los Condes de Treviño fueron los bienes que el Adelantado de León don Pedro Manrique (1381-1440) -destacada 
figura política del reinado de Juan II ${ }^{1}$ - dejó por mayorazgo en 1440 a su primogénito don Diego, quien años después sería I Conde de Treviño. Estos bienes eran el grueso del patrimonio que el Adelantado había heredado de su padre, el también Adelantado aunque de Castilla, Diego Gómez Manrique ( $i-1385)$. Entre ellos destacaba, especialmente, Amusco, el antiguo solar de los Manrique. Este lugar palentino, según se decia en el Becerro de las Behetrías, había sido solariego de Garci Fernández Manrique (i-1362?), de don Gómez Manrique (i-1375), entonces Arzobispo de Santiago — después de Toledo-, y de don Ruy González de Castañeda ${ }^{2}$. Al fallecer este señor los Manrique lograron recuperar la posesión completa sobre Amusco ${ }^{3}$, como se demuestra en la autorización que Pedro I concedió a Garci Fernández Manrique para poner allí un escribano, carta donde el rey afirmaba que este señor poseia "... la justicia y el señorio de dicho lugar»" 4 . Don Garci Fernández Manrique a su muerte dejó su parte de Amusco a su primogénito don Pedro Manrique, al que los genealogistas llarnan VI señor de Amusco ( $i-1381)$, mientras que el Arzobispo de Toledo don Gómez dejó la suya a su sobrino, también eclesiástico, don Juan García Manrique. Poco tiempo compartieron el lugar

\footnotetext{
1 Un excelente retrato de la personalidad de este hombre nos lo brinda Fernán PEREZ DE GuzMÁN en sus Generaciones y Semblanzas, BAE, tomo 68, Madrid, 1953, capitulo XXIV, pág. 708.

Se mencionaba como Hamusco de las Nueve Villas. Gonzalo MARtínez DíEz, Libro Becerro de las Behetrías. Estudio y texto crítico. León, 1981, tomo I, pág. 214. Ignoramos desde qué fecha compartian estos señores Amusco, porque en 1334 don Garci y don Gómez aparecian solos como señores del lugar cuando otorgaron una carta de privitegio al concejo en la que le concedian facultad para constituir unos molinos sobre el rio Ozieza, cuyas rentas serían utilizadas en la honra de Santa Maria y en el "refacimiento de la cerca» de la villa. Además en la citada carta señaiaban que hacían la concesión por los muchos servicios que habian recibido del concejo y prohibian a los de su "linaje" que fuesen contra ello. S.I. 10 de junio de la era de 1372, año de 1334. Real Academia de la Historia (en adelante RAH). Colección Salazar y Castro (en adelante Col. Salazar). M-1. Fol. 97. Puede que Ruy González de Castañeda, ejecutado después por Pedro I, entrase en posesión de una parte de Amusco a raiz de su matrimonio con Teresa de la Vega, hermanastra de don Garci y de don Gómez.

En 1356 don Garci Fernández Manrique decidió llegar a un acuerdo sobre bienes familiares con su hermanastra Teresa de la Vega, para lo que se sometieron al arbitrio de su hermano don Gómez Manrique. Monasterio de Santa Maria la Real en Burgos, 7 de julio de la era de 1394, año de 1356. Luis SAlAzAR y CAStro, Pruebas Históricas de la Casa de Lara, (en adelante Pruebas), Madrid, 1696, pág. 681. Don Gómez determinó que doña Elvira dejase a Garci los vasallos, tierras y derechos que le correspondiesen en Amusco por parte de su madre, a cambio de lo cual él y don Garci le entregarian lo que tenian en Ventosilla, lugar que también habian compartido con Ruy González de Casteñeda, su esposo, además de recompensarla con 15.000 maravedies de la moneda corriente. Parece que todos estaban interesados en quedarse con el dominio completo de los respectivos lugares. Santiago de Compostela, 15 de noviembre de 1356. Pruebas, pág. 682.

4 Carta con sello de plomo dada en Sevilla el 19 de agosto de la era de 1398, año de 1360. RAH. Col. Salazar. M-6. Fol. 211-211v. Pruebas, pág. 46.
} 
don Juan García y don Pedro, por la prematura muerte de éste en 1381 tras su caída en desgracia un año antes. Don Pedro al morir dejó su parte de Amusco al citado prelado para que con ella pudiese hacer cumplir sus mandas testamentarias, pero don Juan, antes que enajenarla, prefirió hacerse cargo con sus propios bienes del cumplimiento del testamento de su hermano, y poder así reunir en sus manos el dominio completo del lugar.

En 1382 don Juan García Manrique, entonces Arzobispo de Santiago, decidió fundar un mayorazgo en favor de su hermanastro don Diego Gómez Manrique con Amusco y la mitad de la villa de Redecilla del Camino. El prelado, además del régimen sucesorio ${ }^{5}$, impuso ciertas condiciones en la fundación del mayorazgo: la posibilidad de revocar la donación si don Diego o sus descendientes fueran desagradecidos y la obligación de todos los herederos de seguir la "voz de los Manrique" y llevar sus armas ${ }^{6}$.

Don Diego Gómez Manrique, VII señor de Amusco para los genealogistas, dejó este lugar en virtud del mayorazgo, a su único hijo Pedro Manrique, el que sería célebre Adelantado de León, como decíamos al comienzo. Asimismo le legó Treviño, Villoslada, Lumbreras y Ortigosa, poblaciones que habia heredado de su hermanastro don Pedro Manrique, el VI señor de Amusco. Enrique II había concedido en 1366 a este señor las citadas villas ${ }^{7}$ con la condición de que fueran de mayorazgo "por línea masculina legítima". En la merced el monarca se encargaba también de fijar el régimen sucesorio: si don Pedro Manrique moría sin hijos legítimos, le sucederian consecutivamente en el mayorazgo sus hermanastros, primero don Garci Fernández Manrique, después don Rodrigo Manrique -aunque ambos solo lo poseerían mientras viviesen-, y por último don

5 En el caso de desaparecer la línea masculina de don Diego Manrique, el Arzobispo establecia que heredase el mayorazgo su sobrino don Garci Fernández Manrique, hijo de su hermano y homónimo el señor de Isar, ya difunto, después don Gómez Manrique, el que seria años más tarde señor de Frómista, hijo bastardo del VI señor de Amusco don Pedro Manrique, y por último los hijos de su hermana Teresa Manrique.

${ }^{6}$ La última condición de don Juan era que si se arruinaba y no podía hacerse cargo del testamento de su hermano don Pedro Manrique, que don Diego lo cumpliese, aunque le prohibia "lançar pecho" en Amusco para ello y le daba de plażo 15 años. Madrid, 17 de septiembre de la era de 1420, año de 1382.RAH. Salazar. M-1. Fols. 107-108. Pruebas, 47-49. También Archivo Histórico Nacional, (en adelante AHN). Sección de Consejos, legajo 23.758.

En la merced se incluian las aldeas y términos de dichas villas, las martiniegas, portazgos, pasajes, recuajes y otros pechos y derechos, divisas, justicia civil y criminal, asi como la capacidad para poder nombre alcaldes, alguaciles, merinos, jurados, escribanos públicos, y otros cualesquier oficiales. Privilegio rodado otorgado en Burgos el 8 de abril de la era de 1401, año de 1366. RAH. 0-20. Fols. 37-38. También en S-59. Fols. 49-65. Pruebas, págs. 49-52 
Diego Gómez Manrique, con la salvedad de que a éste si podian sucederle sus herederos legítimos ${ }^{8}$. La caída en desgracia del VI señor de Amusco en 1380 y su prematura muerte al año siguiente sin sucesores legítimos - ya que sólo tenía un hijo bastardo, Gómez Manrique-, así como el fallecimiento temprano de Rodrigo y Garci pusieron en manos de don Diego Gómez, antes quizá de lo que él habría podido imaginar, las codiciadas villas y otros bienes, que después heredaría su único hijo el Adelantado Pedro Manrique.

Don Diego Gómez también dejó a don Pedro el dominio completo sobre Redecilla del Camino, parte de Ezcaray y de otros lugares cercanos a esta villa logroñesa ${ }^{9}$, y las dos Amayuelas. Además de lo heredado de sus parientes le legó asimismo sus propias adquisiciones: Ocón ${ }^{10}$, Navarrete ${ }^{11} \mathrm{y}$ San Pedro ${ }^{12}$ - poblaciones que le habia concedido Enrique II y Juan 1-, Ribas y Poblacioneja - villas palentinas que había comprado a Alvaro

8 Sólo en el caso de que don Diego no tuviera descendencia legítima masculina permitía el rey que volviera la línea de sucesión a los herederos de don Garci Fernández Manrique, para una vez fenecida ésta, establecer el derecho de los descendientes femeninos, con la condición tan frecuente de que el hombre con el que las señoras estuvieran casadas tomase las armas y la voz de los Manrique. En el caso de que no hubiese ningún descendiente, masculino ni femenino, se establecia que los bienes volviesen a la Corona. Ibidem.

9 Los derechos de los Manrique sobre estas posesiones procedian de doña Urraca de Leiva, la primera esposa de don Garci Fernández Manrique, $V$ señor de Amusco. Este matrimonio lo cita Luis Salazar y CASTRO en su Historia Genealógica de la Casa de Lara (en adelante Casa de Lara), Madrid, 1696, tomo I, pág. 380. En 1375 don Diego Goméz Manrique y su hermana Teresa Manrique hicieron un reparto de vasallos, aldeas, lugares y casas en Ezcaray, Pradilla, Santurde, Zorraquín y Valgañón, así como en sus aldeas y cabañas, con Teresa Leiva, Abadesa del Monasterio de Cañas, con Isabel de Meneses, después abadesa del mismo monasterio, con Juan de Leiva, señor de la Casa de Leiva, y con Gonzalo Núñez de Guzmán, más tarde Maestre de Calatrava, en nombre de su esposa Francisca de Meneses. 17 de mayo de la era de 1413, año de 1375. RAH. Col. Salazar. M-47. Fols. 89-100.

10 Villa que le fue donada por Enrique II en 1379.Cortes de Burgos, 2 de enero de 1379. RAH. Col. Salazar. M-8. Fols. 171-172. Pruebas, págs, 235-236. La donación, por juro de heredad, incluía el casiillo de la villa y todas las otras cláusulas tradicionales referentes a las rentas, justicia y jurisdicción. Ocón había sido donada antes por el rey a Ramiro Sánchez de Asien, pero se la había confiscado por pasarse a Navarra durante la guerra con dicho reino. La villa le fue confirmada a don [iego por Juan I en Valladolid, 2 de febrero de la era de 1418, año de 1380.RAH. Col. Salazar. 0-2-. Fols. 23-33.

11 Merced que le hizo Juan I en diciembre de 1379 y que le confirmó por privilegio el 2 de febrero de 1380. La donación de esta villa incluia sus aldeas y términos, vasallos, vecinos, rentas, pechos, derechos, y la justicia civil y criminal. El monarca establecía la condición de que la villa fuese de mayorazgo y que la heredase su hijo legitimo. s.l. 1 de diciembre de la era de 1417, año 1379. RAH.Col. Salazar. M-1.Fol. 106.

${ }_{12}$ Merced que Juan I le hizo el 18 de octubre de 1383. La donación hecha por juro de heredad incluia todos los vasallos de la villa, los portazgos, martiniegas, pasajes, recuajes, la justicia civil y criminal, mero y mixto imperio, y la autorización expresa para poder poner alguaciles, alcaldes, merinos u otros oficiales, así como escribanos públicos. s.l. 18 de octubre era de 1425, año de 1383. RAH. Col. Salazar. M-8. Fols. 172-173. 
López de la Serna en $1380^{13}$ - y Calabazanos ${ }^{14}$. Don Pedro Manrique heredó, por tanto, un rico patrimonio que le situó en una inmejorable posición socio-económica, pero a pesar del valiniento político que alcanzó en determinados momentos de su ajetreada vida pública no incrementó en exceso la formidable herencia de sus predecesores. No obstante, sabemos que añadió a su rico patrimonio por compra u otros tratos VillartaQuintana, Villahorceros, Baños ${ }^{15}$, Eterna ${ }^{16}$ y Anguiano ${ }^{17}$, y por merced real su adquisición más importante: Paredes de Nava, villa que le concedió Juan II en agradecimiento a sus servicios en 1429. Aparte sabemos que amplió su dominio sobre Ezcaray y otros lugares de sus alredeciores ${ }^{18}$.

13 Este cabaliero poseía la villa de Ribas porque se la había donado por juro de heredad con todos sus términos, pechos, derechos y justicia civil y criminal en agradecimiento a sus muchos servicios don Pedro Manrique, VI señor de Amusco, de quien habia sido vasallo. Navarrete (Logroño), 5 de febrero de la era de 1405, año de 1367. RAH. Col. Salazar. M-1. Fols. 97-97v. La cercanía de Ribas a Amusco debió pesar mucho en la decisión de don Diego Gómez de adquirirla nuevamente para su familia. Don Alvaro le vendió la villa y su casa fuerte por 88.000 maravedies tasados a 10 dineros el maravedi. Carrión de los Condes (Palencia), 5 de agosto de la era de 1418, año de 1380.RAH. Col. Salazar. M-1. Fol. 97v. Dos años después don Diego volvió a vender Ribas a su hermana Teresa Manrique por 70.000 maravedíes, con la condición de que si en los tres meses siguientes le entregaba dicha cantidad, la venta quedaria anulada. Todo parece indicar que don Diego necesitaba dinero, pero debemos creer que devolvió a su hermana los 70.000 maravedies en el plazo estipulado pues Ribas se mantuvo en el patrimonio de sus herederos. Madrid, 15 de diciembre de la era de 1420. RAH. Col. Salazar. M-1.Fols. 97-98.

14 Esta aldea había sido comprada por Pedro Manrique, VI señor de Amusco, y su esposa Teresa de Cisneros a don Diego Garcia de Padilla, Maestre de la Orden de Calatrava. Después se la donaron con su casa fuerte y vasallos a Alvar García de Herrera. En 1375 don Diego Gómez Manrique compró el lugar al citado señor por 91.000 maravedíes. Palencia, 9 de diciembre de la era de 1413, año de 1375. AHN. Sección de Clero, legajo 5.328.

15 El Adelantado compró la villa al Abad y monjes del Monasterio de San Isidro de Dueñas a cambio de un censo de 36 florines de oro del cuño de Aragón. Valladolid, 23 de noviembre. s.a. RAH. Col. Salazar. D-11. Fols. 39-40.

16 Este lugar se lo compró en 1413 a Garci González por 1.500 maravedies de la moneda corriente. Casa de Lara, tomo II, pág. 16.

17 Enrique II habia concedido Anguiano al Adelantado de Castilla Pedro Manrique, el que fuera VI señor de Amusco, con la condición de que no pudiera ser vendida ni donada a la lglesia. Don Pedro hizo donación de la villa a Juan Sánchez de Bruceña, quien en 1383 con licencia regia se la vendió al abad del Monasterio de Valvanera. Puebla de Montalbán, 23 de noviembre de 1383. Archivo de Valvanera. Compendio Grande. Fol. 25. Publicado por F. Javier García Turza, Documentación medieval del Monasterio de Valvanera: siglos XIV-XV. Logroño, 1990, doc. $n^{\circ} 24$. Muchos años después su descendiente don Pedro, el Adelantado de León, logró recuperar la villa para su familia. Gracias a diversos contratos efectuados con el General y el Capítulo de la Orden a la que pertenecía el citado monasterio, se hizo con Anguiano a cambio de 8.000 maravedies de juro.

18 Em 1394 don Pedro Manrique, entonces bajo la protección de su tío el Arzobispo de Santiago Juan Garcia Manrique, quién defendió los derechos de su sobrino sobre Ezcaray y otros lugares cercanos, cuestionados por los Leiva, señores con los que compartian el señorio, llevó a cabo con éstos, como ya hiciera su padre un reparto de vasallos, heredades y derechos. Santurde, 26 de noviembre de 1394. RAH. Col. Salazar. M-40. Fols. 5 y 6 . También en M-57. Fol. 112. En 
Su rico patrimonio le permitió fundar en su testamento seis mayorazgos para sus otros tantos hijos varones ${ }^{19}$, aunque como cabe suponer el núcleo del mismo con los bienes emblemáticos de la familia Manrique pasaría a su primogénito don Diego Manrique que acaparó Amusco, Treviño —sobre la que el joven alcanzaría título de conde en 1452-, Villoslada, Ortigosa, Navarrete, Ocón, San Pedro, Redecilla del Camino, Ribas, Villarta-Quintana, Villaorceros, así como casas, heredades, edificios y castillos que no se especificaban en el testamento del Adelantado Pedro Manrique. El futuro conde de Treviño heredaba, por tanto, un potente señorío diseminado fundamentalmente por la actual comunidad de La Rioja y por la provincia de Palencia, diversos maravedíes de juro, y los oficios de Adelantado Mayor y Notario Mayor del Reino de León que había tenido su padre. Esta considerable herencia le proporcionó una inmejorable posición política y económica para continuar engrandeciendo el poderío y riqueza de su familia, pero don Diego, como sería común entre sus parientes, no supo o no pudo sacar partido de su privilegiada condición.

\section{b) Las adquisiciones de los Condes de Treviño}

En los dieciocho años que mediaron entre la muerte de su padre y la suya, el l Conde de Treviño don Diego Manrique ( $(-1458)$ no consiguió del monarca más favor que el título de Conde que le concedió en $1452{ }^{20}$. Como les estaba sucediendo a sus hermanos, su continua rebeldía política contra Juan II y su valido don Alvaro de Luna le privó de mercedes regias con las que acrecentar sus posesiones económicas. Su prematura muerte en 1458, cuando aún no hacía ni cuatro años que había sido perdonado por Enrique IV, tampoco le dio mucha opción a fortalecer su hacienda en !o que a concesiones reales se refiere.

\footnotetext{
1415 el ya Adelantado de León conseguia ampliar sus dominios, porque Francisca de Meneses, hija de Sancha de Leiva, le empeñó su parte en Ezcaray, Santurde, Zorraquín y Valgañón por dos mil florines de oro del cuño de Aragón. Burgos, 16 de abril de 1415. RAH. Col. Salazar. M-47. Fols. 109-111. También en D-16. Fols. 133-134. Doña Francisca no debió abonar su deuda y don Pedro se quedó con los bienes empeñados, como él mismo reconocía en una donación que hizo a favor de su esposa doña Leonor de Castilla de estos bienes y de otros que tenía en Ezcaray y sus alrededores. Toro, 13 de abril de 1427. RAH. Col. Salazar. M-1.Fol. 101.

19 El Adelantado y su esposa Leonor de Castilla tuvieron ocho hijos varones. A dos de ellos los destinó don Pedro a la Iglesia, y al resto - Diego, Rodrigo, Pedro, Fadrique, Gómez y Garciales dejó diversos bienes vinculados por mayorazgo, que serian el punto de partida, aparte de la línea primogénita, de varias ramas familiares a las que tendremos ocasión de hacer referencia en estas páginas cuando nos ocupemos de sus respectivos señorios.

20 Alonso LOPEZ DE HARO, Nobiliario genealógico de los Reyes y Títulos de España, Madrid, 1622, pág. 304 .
} 
Aun asi don Diego hizo algunas adquisiciones para su señorio. La más importante, Villoido, la consiguió tras un acuerdo con don Iñigo López de Mendoza, que le dio la villa a cambio de los bienes de Guadalajara que don Diego habia heredado de la Duquesa de Arjona Aldonza de Mendoza ${ }^{21}$. En 1435 esta señora había nombrado herederos de sus bienes al Adelantado Pedro Manrique y a su hijo don Diego. Esta disposición testamentaria provocó la reacción airada de don Iñigo López de Mendoza que defendía sus derechos sobre la herencia, y dio lugar a enfrentamientos entre éste y don Diego ${ }^{22}$. En 1442 cansados de tan pesado litigio ambos nobles llegaron a un acuerdo: don Iñigo se quedaría con los bienes de la Duquesa en Guadalajara por estar cercanos a los otros de su patrimonio, pero daría en compensación a don Diego 200.000 maravedíes por unas casas en Guadalajara, y la villa de Villoldo, con la fortaleza, vasallos, jurisdicción, y rentas, además del lugar de Río Ferreros por las villas de Tendilla y el heredamiento de Ledanza ${ }^{23}$.

También adquirió don Diego Manrique por compra el tributo que se conocía como los Moyos de pan y cerraduras sobre la villa de Treviño y sus aldeas. Dicho tributo lo compró a Pedro Ruiz Sarmiento, señor de Salinas y Repostero Mayor del Rey, aunque después, por causas que desconocemos, ambos señores mantuvieron una sangrienta contienda por los derechos sobre el mismo. El tributo, que suponía 1.400 fanegas de «pan» equivalentes a 460.000 maravedies, al final quedó en manos de don Diego Manrique. El concejo de Treviño suplicó entonces al conde y a su esposa que, como recompensa por sus servicios durante la guerra con el Repostero, rebajasen el oneroso tributo de los Moyos, porque la tierra era pobre y la carga del impuesto se hacía insostenible. Ante el temor de que Treviño se despoblase, don Diego decidió convertir el tributo en dinero y rebajarlo. Los condes llegaron a un acuerdo en 1458 con los procuradores de los vecinos y determinaron que el concejo de Treviño pagase sólo

21 Testamento dado en Espinosa el 16 de junio de 1435. Pruebas, págs. 252-255.

22 Véase Pedro CARRILlo DE Huete, Crónica del Halconero de Juan II, (en adelante Halconero). Ed. de Juan de Mata Carriazo, Madrid, 1946, págs. 210-211, y Lope Barrientos, Refundición de la Crónica del Halconero, (en adelante Refundición), Ed. Juan de Mata Carriazo, Madrid, 1946, págs. 187-188.

23. Como era frecuente en la época se sometieron al veredicto de unos jueces árbitros. En la sentencia se adjudicaron a don Diego los bienes objeto de disputa y se aprobó el intercambio de los mismos con don Iñigo. Toro, 21 de febrero de 1442 y Coca, 2 de noviembre de 1442. RAH Col. Salazar. M-4. Fols. 43-45. Después ambos señores consintieron y sancionaron el acuerdo, don Iñigo por una escritura que otorgó en Guadalajara el 25 de febrero de 1443, y don Diego por otra dada en su villa de Navarrete el dia 4 de marzo RAH. Col. Salazar. M-4. Fols. 46-48. Pruebas, págs. 269-270. 
30.000 maravedíes como "censo perpetuo", en lugar de las 1.400 fanegas de «pan» ${ }^{24}$.

Poco había incrementado el Conde de Treviño el rico patrimonio heredado de su padre, por ello en su testamento, otorgado en 1458 , se mostró cauto y prefirió dejar el grueso del mismo por mayorazgo a su primogénito don Pedro. En dicho mayorazgo don Diego incluía además de toda la herencia de su padre y de sus adquisiciones, 100.000 maravedíes de juro ${ }^{25} y$ Ponferrada, villa que también habia heredado de la Duquesa de Arjona pero que estaba en manos de los Condes de Lemos. A su segundo hijo y homónimo, don Diego Manrique le dejaba tan sólo su oficio de Notario Mayor del Reino de León, 20 lanzas del rey, las tenencias de Davalillo y Vellivio, y aquellos bienes que su mujer considerase aparte del mayorazgo ${ }^{26}$.

El II Conde de Treviño don Pedro Manrique ( $i-1515)$, destacado caballero que habia heredado de su abuelo el Adelantado de León no sólo el nombre, sino también su afición por la intriga y el valimiento político, no derrochó esfuerzos para fortalecer sus señoríos con nuevas adquisiciones, y aunque muchos de ellos fueron infructuosos ${ }^{27}$, no cabe duda que dió un notable impulso al patrimonio de su casa. La adquisición más importante que hizo don Pedro fue Nájera, ciudad que le concedió Enrique IV en 1465 con sus castillos y fortalezas, todos los lugares de su tierra, todo su término, distrito y jurisdicción por juro de heredad. El monarca recompensaba asi al Conde por mantenerse fiel a su causa en unos momentos en los que el resto del linaje Manrique le había abandonado por el partido de su hermano el Infante don Alfonso ${ }^{28}$. Nájera le fue confirmada por Fernando el Católico en $1476{ }^{29}$, y sobre

${ }^{24}$ Villoldo (Palencia), 9 de marzo de 1458. RAH. Col. Salazar. M-8. Fols. 179-180v. Pruebas, pág. 271.

25 De esios maravedies don Pedro Manrique solicitaria años más tarde al monarca que se le despachase el correspondiente privilegio. Medina del Campo, 16 de junio de 1463. RAH. Col. Salazar. M-8. Fol. 144.

26 Pruebas, págs. 272-276.

27 El segundo conde de Treviño trató sin éxito de incorporar a su casa Ponferrada, Jubera, Carrión de los Condes y diversas posesiones de la herencia paterna de su madre la condesa de Treviño y de Miranda doña Maria de Sandoval. Estos aspectos se narran detalladamente en la Tesis doctoral inédita de Rosa María MONTERO TEJADA, Los Manrique: linaje noble, sociedad y política en la Baja Edad Media castellana, UNED, 1994, tomo I, págs. 221-246.

28 Donación hecha en el Real cerca de Toro el 30 de julio de 1465. RAH. 9-30-7/6.483. Fol. 257.

29 En la confirmación de Fernando el Católico se instaba a los oficiales del concejo a acatar por señor a don Pedro Manrique como "buenos vasallos» y a que cumpliesen tanto sus cartas y mandamientos como los de los oficiales y personas que el pusiese o mandase poner. Asimismo en su carta el rey aseguraba el conde de Treviño que habia ordenado a los vecinos de la ciudad que 
esta ciudad le concederian en 1482 los Reyes Católicos el título de duque ${ }^{30}$.

Tras sus servicios en la guerra de Granada los Reyes Católicos concedieron en 1492 a don Pedro las villas de Albox, Alborea, Albánchez y Benitagla ${ }^{31}$. Sin embargo, el Duque de Nájera, dada la lejanía de estas posesiones del núcleo de su patrimonio, decidió venderlas dos años después al Adelantado de Murcia, don Juan Chacón por 800.000 maravedies ${ }^{32}$.

Por último recurriendo a la violencia don Pedro Manrique logró hacerse con dos villas de la frontera de Navarra, Genevilla y Cabredo. Estas villas en un primer momento se le habian entregado en encomienda para que las defendiese de las sangrientas luchas banderizas del reino navarro, aunque luego Don Pedro las había retenido como dominio solariego. En 1499 los monarcas de Navarra exigieron al Duque la devolución de dichas villas ${ }^{33}$, pero éste defendió su derecho sobre las mismas alegando que le pertenecian por los muchos daños que sus vasallos habian recibido de los navarros ${ }^{34}$. A pesar de los requerimientos para la entrega de Genevilla y Cabredo el Duque siguió reteniéndolas e incluso se las dejó en herencia a uno de sus hijos bastardos, don Pedro Manrique ${ }^{35}$.

A lo largo de su dilatada vida y gracias a su incansable actividad política, el Duque de Nájera recibió otras mercedes reales que luego por diversas circunstancias no se hicieron efectivas. Ese es el caso de las que le

\footnotetext{
“... vos recudan y fagan recudir a vos el dicho conde don Pedro Manrique o a quien vuestro poder oviere y después de vos a los vuestros herederos... con todos los pechos e rentas e derechos al señorio de la dicha cibdad e su tierra anejos e pertenecientes... en cada un año para siempre jamas..." Vitoria, 16 de julio de 1476. RAH. Col. Salazar. M-22, Fols. 223-224. y M-31. Fols. 69-71.

30 El 30 de agosto de 1482. Alonso LOPEZ DE HARO, Nobiliario..., tomo I, pág. 306.

${ }^{31}$ Privilegio Real dado en la Puebla de Guadalupe el 23 de junio de 1432. RAH. Col. Salazar. M-8 Fols. 170v-171. Pruebas. pág. 294.

32 Medina del Campo, 25 de marzo de 1494. RAH. Col. Salazar. M-8. Fols. 151-151v. Pruebas. pág. 294-295.

33 Castillo de la villa de Pau, 5 de mayo de 1499. CODOIN, tomo XLI, pág. 116.

34 El segundo conde de Treviño mantenía desde tiempo atrás diversos roces con los monarcas navarros, porque algunas de sus posesiones que estaban cercanas a la frontera sufrian numerosas molestias de los habitantes del vecino reino. Por ello, cuando don Pedro Manrique firmó una concordia en 1472 con los entonces Príncipes Isabel y Fernando, se estableció en una de las cláusulas que éstos procurarían que se acabasen los enfrentamientos que el Conde de Treviño mantenía con doña Leonor de Navarra, hermana del Príncipe. y con el Condestable Mosen Pierres de Peralta. Torrelaguna, 22 de diciembre de 1472. Archivo General de Simancas (en adelante A.G. Simancas). Patronato Real, legajo 11, fol. 82.

35 En la cláusula testamentaria el Duque establecia que las villas sólo serían devueltas en el caso de ser indemnizado por los daños que él y sus tierras habian sufrido de Navarra, y de que se le abonase lo que alli habia “labrado". Navarrete, 22 de enero de 1515. RAH. Col. Salazar. M-1. fols. 92-96. Pruebas. págs. 299-304.
} 
ofrecieron los Reyes Católicos, por el apoyo que habia prestado a su causa, en ciertos acuerdos que firmaron con él en $1476{ }^{36}$. Isabel y Fernando, en gratitud por sus muchos servicios, prometieron al entonces conde de Treviño, entre otras cosas ${ }^{37}$, hacerle merced de 1.200 vasallos en los obispados de Osma y Calahorra por una provisión que debían otorgar cinco días después de firmarse los capítulos

«.. firmada e sellada en manos e poder de Gomes Manrrique para que la tenga en depósyto por tiempo de ocho meses contados desde el dia que sus altesas estos capítulos firmaren, con seguridad que ayan de faser e fagan de tener dicha provisyón secreta durante el dicho tiempo... ${ }^{38}$.

En virtud de lo asentado los monarcas dieron una cédula en la que concedían al conde de Treviño los citados 1.200 vasallos por juro de heredad para él y sus sucesores, con todos los derechos excepto los pertenecientes a la Corona ${ }^{39}$. Sin embargo, esta merced no llegó a cumplirse, pues el Duque de Nájera en su testamento pedía que se ejecutase ${ }^{40}$.

36 En ellos el conde exigió a los monarcas que le dieran finiquito de ciertas exacciones de alcabalas, tercias, pedidos y monedas que habia hecho en sus lugares solariegos y encomiendas, -a lo que se habia visto obligado porque en vida de Enrique IV no le habian pagado clos maravedies que tenia en los libros e los derechos de la notaria e otras quantias de maravedies" que gozaba de sueldo por apoyar la causa de los Príncipes--, y que, como habian negociado en el mes de mayo en Valladolid, le abonaran los gastos que habia tenido por defender la villa de Carrión. Por ello los monarcas prometieron darle un cuento de rnaravedies. Además don Pedro Manrique solicitó que los reyes cumplieran la merced que le habian prometido de los bienes de los que sacaban moneda y plata del reino, y que se le abonasen los maravedies de juro que le debían a él y a la condesa. Todas estas exigencias se habian recogido ya en una capitulación anterior entre los Reyes y el conde otorgada en Valladolid. s.I. 2 de marzo de 1476. A.G. Simancas. Patronato Real, legajo 11, fol. 81 .

37 Otras promesas regias fueron: 100.000 maravedies anuales en compensación por el embargo que el Maestre de Santiago Juan Pacheco y su hijo le habian hecho de las tercias de Escalona y el Paso de la Venta del Cojo que tenía por merced de juro su esposa la condesa doña Guiomar, y pagarle en dos meses 2 cuentos de maravedies como compensación por los gastos que habia tenido en aplacar las disensiones del Condado de Vizcaya cuando ellos eran Príncipes. Como garantia los monarcas le entregaban el Corregimiento del Condado en una provisión firmada de sus nombres y sellada, con la condición de que don Pedro Manrique prestase juramento de mantenerla secreta y no usarla durante los dos meses del plazo. Una vez transcurrido éste, si no había recibido lo acordado podía presentar la carta “... e usar del dicho oficio" hasta que se le abonase lo que le correspondia. Ibídem.

38 Su tío Gómez Manrique debia prestar pleito-homenaje de no retrasar la entrega por orden real. Ibidem.

39 s.l. 1476. RAH. Col. Salazar. M-8. Fols. 166v-167.

40 De los 1.200 vasallos dejaba a sus hijos Alvaro, Luis y Pedro Manrique 100 vasallos para cada uno por título de mayorazgo. Navarrete, 22 de enero de 1515. RAH. Col. Salazar. M-1. Fols. 92-96. Pruebas, pág. 299-306. 
Tampoco logró conservar don Pedro Manrique las alcabalas de la Merindad de Nájera, que le habian sido embargadas por Isabel la Católica y que el Archiduque Felipe el Hermoso le concedió nuevamente, aunque sí se le libró su importe del tiempo que medió entre la confirmación de la merced y la anulación de la misma ${ }^{41}$.

\section{El señorio de los Condes de Paredes}

\section{a) El núcleo del señorío: Paredes de Nava}

El origen del señorío de los Condes de Paredes está en la merced que hizo Juan II en 1436 al joven Rodrigo Manrique (1412?-1476) -entonces Comendador de Segura en la Orden de Santiago- por sus servicios en la toma de Huéscar: los lugares de Cenilla, Matilla, el Pozo, Robledillo y Balazote, pertenecientes a la jurisdicción de Aicaraz ${ }^{42}$. Sin embargo, el principal impulso para el patrimonio de don Rodrigo fueron los bienes que le dejó por mayorazgo su padre el Adelantado Pedro Manrique cuando otorgó testamento en 1440: 20.000 maravedies de juro y Paredes de Nava ${ }^{43}$, villa que le había concedido Juan II en 1429 tras el despojo de bienes sufrido por los Infantes de Aragón ${ }^{44}$. De la villa palentina de Paredes de Nava diría G. Fernández de Oviedo que era "una de las buenas piezas de señor que ay en Castilla" " ${ }^{45}$, y durante largo tiempo sería núcleo fundamental del señorio de esta rama de los Manrique.

41 A.G. Simancas. Mercedes y Privilegios, legajo 78. fol. 11. Su hijo Antonio Manrique, II Duque de Nájera, seguiria demandando a la muerte de su padre estas alcabalas, según consta en un Memorial enviado a Carlos I el 30 de julio de 1516. A.G. Simancas. Diversos de Castilla, legajo $39, n^{\circ} 32$.

42 Esta concesión fue hecha el 20 de diciembre de 1436 y confirmada por privilegio al año siguiente. Roa, 6 de abril de 1437. Pruebas, págs. 380-383.

43 Valladolid, 20 de septiembre de 1440. RAH. Col. Salazar. M-2. Fols. 83-93. Pruebas, págs. 256-261. El Adelantado estabiecía que si le quitaban por cualquier motivo esta villa que recibiese Ocón. Don Rodrigo tomó posesión de Paredes tres dias después del fallecimiento de su padre, el 23 de septiembre de 1440. Pub. por el Padre Tomás TERESA, Historia de Paredes de Nava, Palencia, 1968, pág. 183.

44 Esta concesión que según se dice en el documento fue por dar "galardón" a los servicios de don Pedro Manrique, incluia además de la villa de Paredes, su término, vasallos, moradores, pechos, derechos, penas y calumnias pertenecientes al señorio de la villa y su tierra, las martiniegas, yantares, escribanias, portazgos, etc. También incluia la justicia civil y criminal alta y baja, mero y mixto imperio y los regimientos de la villa. Sólo se exceptuaba como era habitual, la mayoría de justicia, las alcabalas, monedas, tercias, pedidos y minas. Albalá dado en Medina del Campo el 8 de diciembre de 1429. Privilegio otorgado en Valladolid, el 3 de julio de 1430. Pruebas, págs. 246-250.

45 Gonzalo FERnANDEZ DE OVIEDO, Batallas y Quinquagenas, Ed. de la Real Academia de la Historia, Madrid, 1983, pág. 307. 
Con la herencia paterna el por entonces exiguo patrimonio del Comendador de Segura se consolidó notablemente, pero su participación en los diversos altercados políticos en contra del monarca y su valido don Alvaro de Luna en los años siguientes produjo un profundo malestar en el rey que optó por confiscarle la villa paredeña. El 15 de julio de 1444 Juan Il ordenó a los vecinos de Paredes que no recibiesen a señor alguno, ni al Adelantado Diego Gómez Manrique ni al Comendador -en referencia a don Rodrigo- ni a las gentes de armas que estuviesen a favor del Rey de Navarra. Además en premio a los servicios de los paredeños anulaba la merced hecha a don Rodrigo y les aseguraba su reinserción en la Corona Real ${ }^{46}$.

Tras un intervalo de varios años en cuyo transcurso parece que Juan II había entregado la villa de Paredes a la reina Isabel de Portugal ${ }^{47}$, don Rodrigo Manrique recobró su posesión. En 1452 el comendador de Segura reconocía como legítimo Maestre de Santiago a don Alvaro de Luna y abandonaba la resistencia armada que había mantenido hasta entonces por el maestrazgo santiaguista. Como premio el rey, el 10 de mayo de 1452, le devolvía Paredes de Nava y le hacía conde de ella ${ }^{48}$.

A pesar de que Paredes de Nava era una de las posesiones más importantes de esta rama de los Manrique, y que sobre ella se erigia su título condal, los condes de Paredes estuvieron siempre más pendientes de sus posesiones en el sur -en concreto en las tierras de Alcaraz, donde prácticamente fijaron su residencia- que de la villa paIentina ${ }^{49}$.

46 Archivo Municipal de Paredes de Nava. Publicada por Tomás Teresa, Historia de Paredes..., págs. 184-188. También recompensó los esfuerzos de los vecinos con la exención temporal de pedidos y monedas por cuatro años. 25 de julio de 1444. Archivo Municipal de Paredes de Nava. Carpeta $4^{a}, n^{\circ} 7$. Cit. por Juan Carlos MArtín CEA, El mundo rural castellano a fines de la Edad Media: El ejemplo de Paredes de Nava en el siglo XV, Valladolid, 1991 pág. 66 , nota 167 . El rey les concedió esta merced tras ser informado de que los paredeños no solo no habian acogido en la villa "nin en el alcácar della al adelantado Diego Gomes Manrique nin a ninguno de sus hermanos", sino que incluso los habian repelido por las armas. Durante la tenaz resistencia murieron y fueron heridos algunos vecinos. Archivo Municipal de Paredes de Nava, Carpeta $4, n^{\circ} 21$. La carta se conoce gracias a un traslado que fue sacado de la misma el 2 de septiembre de 1450. Juan Carlos Martin CEA, El mundo rural castellano..., pág. 65, nota, 165.

47 Véase J.C. MaRtín CEA, El mundo rural castellano..., pág. 68.

48 Pruebas, págs. 385-388.

49 Sobre la profunda señorialización a la que sometieron la villa los condes y otros pormeno res es imprescindible la consulta del libro de Juan Carlos MARTIN CEA, El mundo rural castellano... págs. 69,73 y 74 . 


\section{b) El señorío de los condes de Paredes en tierras de la jurisdicción de Alcaraz}

Como decíamos al comienzo Don Rodrigo Manrique, entonces Comendador de Segura en la Orden de Santiago, por los servicios prestados al rey Juan II en la toma de Huéscar recibió por merced en 1436 Cenilla, Matilla, el Pozo, Robledillo - estas dos últimas después llamadas Villapalacios y Villarrobledo respectivamente- y Balazote, lugares pertenecientes a la jurisdicción de Alcaraz ${ }^{50}$. A. Pretel Marín, en una de sus obras sobre la ciudad alcaraceña, asegura que Rodrigo Manrique trató pronto de extender sus posesiones en esta área recurriendo incluso para ello a la apropiación indebida de villas y lugares, y así afirma que en los años siguientes el Comendador debió de apoderarse de Bienservida y Villaverde, villas, asimismo, del término alcaraceño, y que el rey hubo de aprobar, en cierta manera, los hechos consumados ${ }^{51}$.

Tanto los pequeños lugares concedidos por el monarca como las otras villas, usurpadas o no, fueron el germen de un señorío para cuya expansión don Rodrigo Manrique tenía grandes y ambiciosos planes. Por ello no tardó en poner sus ojos en la ciudad de Alcaraz, adquisición, que de haberla logrado, habría dado el impulso y la fortaleza necesarios para sus pretensiones de formar un potente señorio en esas tierras.

La primera oportunidad para hacerse con la ciudad alcaraceña vino de la mano de la coyuntura política. En el transcurso de su rebeldía contra Juan Il y su valido don Alvaro de Luna por el Maestrazgo de Santiago, cansado ya de una lucha que a todas luces parecia inútil y mientras se hallaba refugiado en su Encomienda de Segura de la Sierra, don Rodrigo consideró que había llegado el momento de deponer las armas y negociar con el monarca su rendición. Envió entonces al Rey unas condiciones de paz en las que aceptaba renunciar a sus supuestos derechos al Maestrazgo a cambio de que el rey le concediera Alcaraz y algunas encomiendas santiaguistas. Tanto era su interés en la ciudad alcaraceña que llegó a proponer a Juan II el trueque de su villa de Paredes por ella. Como Alcaraz pertenecía al Príncipe don Enrique, don Rodrigo proponía al rey que éste fuera resarcido de la pérdida con Huete. Juan II llegó a considerar el trato y llamó a la corte a don Rodrigo para discutir las condiciones propuestas, pero al parecer el Rey de Navarra, que no deseaba entonces un acuerdo del monarca

\footnotetext{
50 Véase nota 42.

51 Aurelio Pretel Marin, Una ciudad castellana en los sigios XIV y XV: Alcaraz 1300-1475), Albacete, 1978, pág. 81 .
} 
castellano con este grande, le hizo sospechar que la entrevista podia ser una trampa y don Rodrigo rompió las negociaciones ${ }^{52}$.

Este primer intento de apoderarse de Alcaraz no tuvo, por tanto, éxito, pero tampoco amedrentó a don Rodrigo que intentó conseguir por la fuerza lo que no había logrado por otras vías. Así, el ya Conde de Paredes desde 1452 inició toda una serie de duros hostigamientos contra el concejo de Alcaraz y su tierra a través de sus oficiales: incautaciones de bienes y ganado de mercaderes de la ciudad, presiones sobre los habitantes de las aldeas de la Sierra alcaraceña, usurpación de la jurisdicción y apropiaciones indebidas de derechos y territorios. A estos agravios la ciudad respondía con las mismas armas, y perpetraba actos similares sobre los vasallos del conde ${ }^{53}$.

En 1465 aprovechando el latente clima de guerra civil el hijo mayor del conde de Paredes don Pedro Manrique, que como pronto pondrá de manifiesto compartirá con su padre el deseo de construir un poderoso señorío en las tierras alcaraceñas, y su hermano don Diego atacaron Alcaraz, probablemente con el total beneplácito paterno. Con un fuerte ejército entraron en el término alcaraceño destruyendo las cosechas y robando el ganado. Después pusieron sitio a la ciudad, pero la resistencia de la misma obligó a don Pedro a concertar una entrevista con algunos representantes concejiles, que no cedieron ante las amenazas ni sobornos del magnate para que Alcaraz fuera entregada. Al tiempo que las diversas emboscadas fracasaban y que las continuas destrucciones de molinos y otros bienes tampoco hacian mella en el ánimo de los alcaraceños, don Pedro Manrique veía como sus tropas sufrían numerosas pérdidas, siendo la más dolorosa la muerte de su hermano don Diego, que en el transcurso del asedio fue alcanzado por una lombarda arrojada por los de la ciudad y muerto ${ }^{54}$. El fallecimiento de su hermano, la duración del sitio, y los cambios en la política castellana hicieron a don Pedro levantar el asedio, tras previamente asolar el lugar de La Solanilla donde estaban asentados, y

52 Información obtenida de don Juan TorRes Fontes, Don Pedro Fajardo, Adelantado Mayor del Reino de Murcia, CSIC, Madrid, 1953, pág. 37. También la refieren A. PRETEL Marín en Una ciudad castellana..., pág. 96, e Isabel PASTOR BODMER, Grandeza y tragedia de un valido. La muerte de Don Alvaro de Luna, Madrid, 1992, vol. I, pág. 133, pero ninguno da la fuente.

53 Para Aurelio Pretel, que ha estudiado pormenorizadamente la cadena de abusos cometida por el conde y sus allegados, todo ello respondía a un plan preconcebido de don Rodrigo, que pretendia despoblar aldeas amedrentando a sus moradores, con lo que el valor de la tierra bajaba y él o sus oficiales podian luego comprar más tarde a un precio más bajo. Además sus lugares se fortalecían con la llegada de nuevos pobladores procedentes de las localidades hostigadas. Aurelio Pretel Marin, Una ciudad castellana..., pág. 107.

54 Ibidem..., pág. 130 
ordenar a sus hombres que hiciesen cuantos destrozos pudieran en las propiedades de la ciudad, llevándose como botín 50.000 reses de ganado ${ }^{55}$. El nuevo intento de hacerse con Alcaraz también habia fracasado.

En 1467 don Rodrigo Manrique, sumergido en costosos gastos para mantener su continua actividad política y militar, autorizaba a su criado Alfonso de Torres para vender su villa de Bienservida ${ }^{56}$, lo que indica que el entonces Condestable, como sería frecuente en él, andaba en una mala situación económica. Finalmente en 1468 adquirió la villa su hijo don Pedro Manrique por 600.000 maravedíes ${ }^{57}$, joven que, como ya dijimos, habia heredado de su padre el empeño por construir un estado señorial en las tierras alcaraceñas y que, por tanto, debió preferir adquirir él la villa que permitir que cayera en manos ajenas. La ubicación de Bienservida era además inmejorable, porque compartía sus términos con la Orden de Santiago, de la que él era Comendador, con otras de sus villas y con su ansiada Alcaraz.

No era, sin embargo, la primera venta que ralizaba don Rodrigo Manrique, pues en 1454 había vendido Villarrobledo al Marqués de Villena ${ }^{58}$, en 1461 Balazote a Gonzalo Tapia ${ }^{59}$, Villapalacios, porque su hijo don Pedro compró este lugar por 500.000 maravedies de la moneda corriente en 1470 a los hijos y herederos del Comendador Alvaro de Madrid ${ }^{60}$, y debemos

55 Ibidem, pág. 130. Este autor narra con detalle todos los incidentes.

56 Le daba permiso para venderla por la cantidad de florines, doblas, enriques, o cuantias de maravedies que el considerase conveniente. Garcillán, aldea de Segovia, 8 de octubre de 1467 . Pruebas, págs. 389-390.

573 de abril de 1468. Cit. por Luis Salazar y CASTRo, Casa de Lara, tomo II, pág. 334. Tanto esta villa como Villapalacios, según tendremos ocasión de ver después, las adquirió durante su matrimonio con doña Leonor de Acuña, pues en su testamento dice que él y su esposa "... ovimos e ganamos las villas de Bienservida e Villapalacios con sus vasallos e tierras e jurediçiones çebiles e criminales, altas e baxas e mero e misto ymperio...". Siles, 29 de septiembre de 1482. Pruebas, págs. 414 y ss.

584 de agosto de 1454. Archivo de los Duques de Frias, Caja 3, nº 6 . Dato tomado del Inventario del Archivo de los Duques de Frias, de Pilar León Tello y $M^{a}$ Teresa Peña Marazuela. Madrid, 1955-1973.

59 Aurelio Pretel Marín, Una ciudad castellana..., pág. 137.

60 Lo adquirió con su término, vasallos, pechos y derechos, jurisdicción civil y criminal. Ubeda, 31 de agosto de 1470. RAH. Col. Salazar. M-9. Fols. 173v-174. Años más tarde uno de los herederos y homónimo del Comendador Alvaro de Madrid, vecino de Villamanrique, reclamó al Conde de Paredes la quinta parte de Villapalacios que le correspondia de su padre Sancho de Madrid, porque afirmaba que el dinero de la venta de la misma, que él no había autorizado, se lo habia quedado su tutor. Rodrigo Manrique, III conde de Paredes, delegó la resolución del litigio en un árbitro que determinó que por derecho le diese a don Alvaro de Madrid un potro y 50.000 maravedies, de los que le pagaría 10.000 en 1503 y los otros 40.000 en los ocho años siguientes. Don Alvaro se dio por contento con esta sentencia y prestó juramento de no volver a reclamar nada al Conde. 16 de febrero de 1503. Luis Salazar y CaStro, Casa de Lara, tomo ll, pág. 357. 
pensar que hizo lo mismo con los otros lugares concedidos en 1436 por Juan II, ya que ninguno de ellos aparecerá mencionado ni en su testamento ni en el mayorazgo de su sucesor Pedro Manrique. Con la compra de Villapalacios don Pedro Manrique, más tenaz que su padre, continuaba las gestiones para fortalecer su propio señorio en las tierras alcaraceñas. Villapalacios colindaba con Bienservida - que como decíamos más arriba compró en 1468 - por lo que era una adquisición muy beneficiosa para sus intereses y redondeaba sus posesiones, ya que en fecha que no conocemos, aunque antes de casarse según él mismo reconocía en su testamento, había conseguido asimismo Villaverde, población que también debió de vender su padre ${ }^{61}$.

La estrecha colaboración durante la guerra civil castellana de don Pedro Manrique con el Maestre de Santiago su padre en la toma de Alcaraz para la Corona y su participación en las campañas andaluzas le serían recompensadas por los Reyes Católicos en 1477 con la merced de las tenencias, justicia, jurisdicción, alcabalas, tercias y derechos de Riópar, Cotillas y San Vicente ${ }^{62}$, lugares que los partidarios del Marqués de Villena habian usurpado a la ciudad de Alcaraz, y que el propio Pedro Manrique había tomado por las armas en 1474 y $1475^{63}$. Con esta adquisición el conde de Paredes fortalecía sus posesiones sureñas. La merced real provocó, sin embargo, un gran descontento en Alcaraz, que inició diversas reclamaciones ante los reyes que no tuvieron ningún éxito, porque los monarcas debian mucho a la fidelidad de don Pedro y sobre todo a la de su padre el Maestre don Rodrigo ${ }^{64}$.

61 El Conde dice así: “... e por quanto al tiempo que yo casé con la dicha condesa mi muger troxe al casamiento la mi villa de Villaverde con su tierra e vasallos e con la juredición çevil e criminal aita e baxa mero misto ymperio e con las rentas e pechos e derechos al señorio de la dicha villa debidos e anexos...". Siles, 29 de septiembre de 1481. Pruebas, págs. 414 y ss.

52 Ocaña, 15 de enero de 1477. Pruebas, pág. 412. AHN. Consejos, legajo 27.910. En la referida merced los monarcas hacian constar que si durante la vida de don Pedro o la de su sucesor los Reyes ordenaban que dichas fortalezas volviesen a la jurisdicción de Alcaraz o hiciesen merced de ellas a cualquier otra persona, el conde y sus sucesores deberían ser compensados por los gaștos que habían realizado durante el sitio del Castillo de Riópar y por lo que hubiesen gastado en la mejora de las fortificaciones y edificios.

63 Sobre el asedio y conquista de Riópar se puede ver la información que aparecia en los testimonios de algunos de los protagonistas de los hechos ya ancianos o de sus hijos, en el proceso que siguió la ciudad de Alcaraz contra los condes de Paredes para la recuperación de esos lugares en 1536. AHN. Consejos, legajo 27.910. Véase también A. Pretel Marin, Una ciudad casteIlana..., pág. 150 y del mismo autor “Noticias sobre el Castillo de Riópar en la Edad Media", AlBasit, n 2, págs. 18 y 19.

${ }^{64}$ Sobre estos pleitos pueden consultarse la documentación existente en el AHN. Sección de Consejos. Legajo 27.910. 
A. Pretel Marin afirma que don Pedro Manrique, como su padre muchos años antes, no se conformó con lo que había obtenido en las tierras alcaraceñas, sino que siguió hostigando, especialmente desde Riópar a las villas y lugares cercanos, obligando incluso a intervenir a Fernando el Católico en su defensa ${ }^{65}$. Los diversos incidentes con el concejo alcaraceño continuaron y la ciudad se vio en la necesidad de mantener costosos pleitos con los condes de Paredes por cuestiones referentes a la jurisdicción de la ciudad, alargándose muchos de ellos hasta bien entrado el siglo XVI ${ }^{66}$.

\section{c) La evolución del señorío a la muerte del primer conde de Paredes}

El primer Conde de Paredes Rodrigo Manrique en lugar de incrementar su patrimonio lo fue dilapidando en costosas campañas militares que apenas dieron fruto. Algunos intentos del Conde por ampliar su estado, como fueron sus pretensiones de hacerse con la ciudad de Alcaraz o con la villa de Cardeñosa ${ }^{67}$, fueron fallidos. La poca afortunada trayectoria política de Don Rodrigo influyó mucho en su penosa situación económica. Las únicas mercedes "regias" de valor fueron las que recibió del Príncipe Alfonso, como las Tercias de Paredes de Nava, Cardeñosa y Villanueva del Rebollar ${ }^{68}$, y la concesión de 700.000 maravedíes durante cuatro años ${ }^{69}$. También recibió del joven "monarca" ciertas cantidades de maravedíes de juro de muy diversa consideración ${ }^{70}$.

No se puede acusar, por tanto, de mala gestión económica a don Rodrigo Manrique, más bien el Maestre de Santiago cometió el error de embarcarse en empresas militares que superaban sus medios económicos, por lo que llegó a endeudarse gravemente y hubo de recurrir a préstamos - como los que le hizo su tercera esposa Elvira de Castañeda,

65 A. Pretel Marín, Una ciudad castellana..., págs. 189-190.

56 Véase AHN. Sección de Consejos. Legajo 29.710 y A.G. Simancas. Consejo Real, legajo $68, n^{\circ} 4$.

67 Esta villa de Behetría se habia encomendado al Conde de Paredes, quien después trató de hacerla solariega. Se narran los pormenores en una provisión de los Reyes Católicos dada en Toledo el 19 de mayo de 1480. A.G. Simancas. Registro General del Sello (en adelante Sello). fol. 13.

68 Arévalo, 15 de octubre de 1465. Pruebas, págs. 387-388. También en A.G. Simancas. Mercedes y Privilegios, legajo 10, fol. 130 .

69 De estos últimos solo le dio en cuenta el Infante 80.000 maravedíes, porque la conflictiva situación del reino impedía hacer efectivas las mercedes. Arévalo, 6 de marzo de 1468. A.G. Simancas. Mercedes y Privilegios, legajo 78, fol. 14.

70 A.G. Simancas. Mercedes y Privilegios, legajo 78, fol. 14 y legajo 10, fol. 130 . 
según él mismo reconoce en su testamento-, a apropiarse de bienes que no eran suyos - como cuando enajenó la dote de su nuera Guiomar de Meneses ${ }^{71}-$, o a vender algunas de sus posesiones, muchas de las cuales afortunadamente volvió a comprar su hijo. No es de extrañar, por tanto que de él dijera Fernando del Pulgar que:

"Usaua de tanta liberalidad, que no bastava su renta a sus gastos; ni le bastára si muy grandes rentas e tesoros toviera, segund la continuación que tovo en las guerras" 72 .

A tal punto llegó su situación económica que cuando en 1476 otorgó su testamento, don Rodrigo reconocía que no tenía ni para enterrarse ${ }^{73}$, y tan solo dejaba a su primogénito la villa de Paredes de Nava y su alcázar, lo mismo que él había recibido de su padre, si exceptuamos el título de conde. De sus otros seis hijos, sólo recibían algunos maravedies de juro Jorge Manrique, el célebre poeta, y Fadrique Manrique.

Esta era la situación económica que heredaba el // Conde de Paredes don Pedro Manrique ( $i-1481)$, quien tuvo que dedicar todos sus esfuerzos a cimentar el escaso patrimonio heredado de su padre. Su mayor interés fue construir, como hemos visto, un señorío en las tierras próximas a Alcaraz, pero la fortuna tampoco le sonrió especialmente. Cuando falleció su padre, parecía estar en una situación inmejorable para recoger los frutos de los muchos trabajos de su progenitor el Maestre y asi se plasmó en la merced regia de las Tenencias de Riópar, Cotillas y San Vicente, que se mostraba como la primera recompensa de los Reyes Católicos a sus servicios y a los paternos, pero todo se trastocó con su prematura muerte en 1481. En su testamento otorgado en Siles el 29 de septiembre de ese año dejaba el mayorazgo de Paredes de Nava a su hijo Rodrigo, un niño de corta edad. En una de las cláusulas solicitaba a su esposa doña Leonor de Acuña que agregase al mayorazgo, previa solicitud regia, las villas de Bienservida, Villapalacios y Villaverde ${ }^{74}$.

\footnotetext{
71 Según ella misma señalaba en una queja presentada a los monarcas al quedarse viuda. Toledo, 28 de enero de 1480. A.G. Simancas. Sello. Fol. 161.

72 Fernando Del Pulgar, Claros Varones de Castilla, Madrid, 1969, pág. 95.

73 Don Rodrigo dice: «... Otrosi mando que si el Rey don Fernando e la Reyna doña Isabel, mis señores, acatando los serviçios que a sus altezas e hecho e como e vendido todo lo que tenia fuera de mi mayorazgo, usando de su real nobleza e virtud, en remuneración de lo servido me quisiesen facer alguna merced, pues por los servir no dexo para enterrarme..." Ocaña, 21 de octubre de 1476. Pruebas, págs. 399-401. Después de hacer testamento los monarcas le abonaron ciertas cantidades de maravedies que fueron utilizadas para saldar algunas deudas, pero sus muchos servicios a los reyes fueron escasamente recompensados.

${ }^{74}$ Siles, 29 de septiembre de 1481. Pruebas, págs. 412 y ss.
} 
En 1489 los Reyes Católicos daban licencia a doña Leonor para incluir dichas villas en el mayorazgo, asi como ciertos maravedies de juro ${ }^{75}$. A estas posesiones añadiría esta señora en su testamento otros bienes inmuebles rústicos y urbanos ${ }^{76}$, aunque no mencionaba en él las ricas Salinas de Cotillas que habia comprado al Marqués de Villena en 1482 por 450.000 maravedies ${ }^{77}$.

Tanto la condesa doña Leonor de Acuña, como su hijo el III Conde de Paredes Rodrigo Manrique ( -1536$)$, siguiendo lo que ya era tónica familiar, estuvieron más dedicados a sus posesiones sureñas que a la villa de Paredes de Nava, tanto es así que la propia doña Leonor debia de residir en Villapalacios, lugar donde precisamente otorgó su testamento. En él señalaba su deseo de ser enterrada en Villaverde, en el caso de que no pudiera serlo en Uclés al lado de su marido, lo que indica la vinculación de esta señora con el señorio sureño, y la cierta relegación de la villa paredeña. Lo mismo puede decirse de su hijo Rodrigo quien al igual que su madre eligió como lugar de sepultura el Monasterio de San Francisco de

75 Los soberanos narran en la licencia que el conde quería que las «... villas de Bienservida e Villapalacios e Villaverde con sus tierras e jurediçiones ceviles e criminales e alta e baxa, mero misto ymperio, con las rentas e pechos e derechos al señorio de las dichas villas e de cada una dellas anexos, e con más todas las casas e fortalesas e hedificios e labores e huertas e con otros qualesquier heredamientos que en las dichas villas e en qualquier dellas en los términos e juridiçiones de la çibdad de Alcaras, e con los ochenta mill maravedies de juro aquel dicho conde tenya sytuados en la villa de la Membrilla e en otros logares sus terminos perteneçjentes..." se integrasen en el mayorazgo de los condes de Paredes. Medina del Campo, 20 de marzo de 1489. A.G. Simancas. Sello. Fol. 5.

76 Un gran número de casas principales que la condesa había adquirido en Villapalacios; dos herrerias; varias huertas, viñas y heredades de pan; las casas del Palacio y la Torre en la que "posava" la condesa; otras casas diversas en Villaverde; una Sierra de Agua en el término de la villa de Segura y otros bienes que no detalla. Testamento otorgado en Villapalacios el 1 de octubre de 1501. Pruebas, pág. 420-424.

77 Por esta propiedad los condes de Paredes habían mantenido diversos pleitos con la ciudad de Alcaraz y con el Marqués de Villena don Diego López Pacheco, su último poseedor. En 1477 , a pesar de las demandas de los alcaraceños que reclamaban sus derechos sobre las salinas, una sentencia real las adjudicó al II Conde de Paredes don Pedro Manrique, puesto que se las habian concedido los monarcas como premio a sus servicios durante la guerra civil. Sevilla, 23 de diciembre de 1477. A.G. Simancas. Sello. Fol. 555. Sin embargo, en los acuerdos de los monarcas con el Marqués tras su nueva rendición en 1480 se estableció que podría conservar las Salinas de Pinilla. Bogarra y Cotillas, que antes se le habian confiscado por su rebeldia. Los condes de Paredes se resistieron a desprenderse de ellas, pero los Reyes ordenaron a sus arrendadores que entregasen a don Diego López Pacheco las rentas de las mismas y conminaron repetidamente a don Pedro Manrique para que devolviese las salinas. Medina del Campo, 7 de noviembre de 1480. A.G. Simancas. Sello. Fol. 85. Medina del Campo, 17 de noviembre de 1480. A.G. Simancas. Sello. Fol. 104. 15 de diciembre de 1480. Archivo de los Duques de Frías. Caja 7, $n^{\circ} 25$. Dato tomado del inventario de Pilar León Tello y Ma Teresa PEÑA MARAZUelA. Para acabar con la disputa se decidió finalmente en 1482 la venta de las salinas. Córdoba, 20 de mayo de 1482 . Casa de Lara, tomo li, pág. 340 . 
Villaverde, lo que muestra el estrecho contacto de la familia con su señorío del sur.

\section{El señorío de los Condes de Castañeda y Marqueses de Aguilar de Campoo}

\section{a) El punto de partida}

El origen del señorío de los Condes de Castañeda está en la pequeña herencia que recibió don Garci Fernández Manrique (¿-1436), años después Conde de Castañeda, de su padre y homónimo. Éste a su vez había heredado del suyo Isar, lugar de Burgos que el "Becerro de las Behetrías" llamaba "Cámara de los Manriques" ${ }^{78}$, y diversas heredades en Villanueva Mogina, Villanueva del Páramo y San Martín de Elines, todos ellos lugares solariegos de su padre ${ }^{79}$. En 1370 Enrique II, en agradecimiento al apoyo que don Garci había prestado a su causa durante la guerra civil, le hizo merced de las que serían sus posesiones más importantes, la villa salmantina de Fuenteguinaldo y el lugar de El Villar ${ }^{80}$. Fuenteguinaldo pertenecía a don Sancho, conde de Alburquerque y hermano del rey, y por ello don Garci tardó en ver en sus manos la villa, ya que dos años después de la concesión Don Sancho, que se resistía a desprenderse de ella, aún no se la había entregado. Enrique II tuvo que escribir insistentemente al conde de Alburquerque para que cediera dicho señorío a su nuevo dueño ${ }^{81}$. También la propia Fuenteguinaldo se resistía a aceptar a don Garci como

78 Libro Becerro de las Behetrías. ed. cit., tomo II, pág. 283.

79 Alcalá de Henares, 6 de febrero de la era de 1402, año de 1388. Pruebas, págs. 690-693. No debian ser éstos los únicos bienes que heredó de su padre, porque en 1369 donaba a Juan Ochoa de Valdivieso, morador en Celada de Candemuño, por los servicios que le había hecho y los que le haría en el futuro, todas las heredades de pan y vino, vasallos, solares poblados y sin poblar, huertas y demás bienes que poseía en Valdeporras, Sotocuevas y Valdenocedo, según lo tenía de su padre, con la facultad para disponer de ellos libremente. Cucho, aldea de Treviño, 6 de noviembre de la era de 1407, año de 1369. RAH. Col. Salazar. M-58. fols. 114-115. También su hermano Rodrigo Manrique donó a este mismo señor los bienes que tenia en estos lugares. Burgos, 2 de enero de la era de 1408, año de 1370. RAH. Col. Salazar. M-58. Fols. 114r-115.

80 El monarca le concedió estas posesiones por sus buenos y leales servicios, especialmente por "el trabajo" que sufrió en su ayuda. Fuenteguinaldo se la donó por juro de heredad con todos sus derechos, términos, mero y mixto imperio, y la justicia civil y criminal. Asimismo, le autorizaba a poner alcaldes, alguaciles y escribanos, o cualquier otro oficial. Esta donación se la hacia en enmienda de otra que le habia hecho de ciertas aldeas de Soria. Privilegio Rodado otorgado en Alcalá de Henares el 13 de mayo de la era de 1408, año de 1370. RAH. Col. Salazar. M123. Fols. $12 v-19 \mathrm{v}$.

81 Gradefes, 4 de junio de la era de 1410, año de 1372. Ibídem. Una de las últimas cartas del rey debió surtir efecto, porque unos días después don Sancho escribía al concejo de 
su señor e intentaba hacer valer las promesas, posiblemente regias, de que pasaría al realengo ${ }^{82}$, pero finalmente tuvo que ceder, lo mismo que el lugar de El Villar, cuyos vecinos se entregaron como vasallos unos días después de que lo hubieran hecho los de Fuenteguinaldo ${ }^{83}$.

Aunque no conocemos el testamento de don Garci Fernández Manrique, sabemos que su hijo y homónimo patrimonializó Isar, Villanueva, San Martín de Elines, Fuenteguinaldo y su término, además de diversos bienes en Celadilla y Piña de Campos. Tras el fallecimiento de su padre, don Garci dedicó sus esfuerzos a fortalecer $e$ incrementar su por entonces pequeño patrimonio. Para ello, lo primero que hizo fue concertar un ventajoso matrimonio con doña Aldonza Téllez de Castilla, que le permitió acceder a los señorios de Castañeda y Aguilar de Campoo, y después procuró solventar diversos pleitos sobre posesiones. En primer lugar hubo de resolver la querella que mantenía con el señor de Camporredondo sobre algunos lugares de Behetría que ambos poseían, especialmente por Tabanera, del que se había apropiado. Esta disputa habia dado lugar a una serie de enfrentamientos violentos entre ambos señores y sus vasallos, por lo que en 1398 trataron sin éxito de lograr una concordia ${ }^{84}$. La contienda continuó con la misma virulencia hasta que en 1405 llegaron a un acuerdo ${ }^{\text {85: }}$ don Garci entregaría Tabanera a don Pedro y le recompensaría por los daños que había sufrido en su lugar de Tablares; las behetrías podrían elegir libremente a su señor, excepto las de Valdavia que quedaban al arbitrio del Infante don Fernando, quien asimismo determinaría lo que correspondía a cada uno de sus naturalezas en los lugares que disputaban; por último, sus hombres y escuderos podrian vivir en los lugares del otro y los labradores «correr monte" como habia sido costumbre ${ }^{86}$.

Fuenteguinaldo para que recibiera por señor a don Garci. Ciudad Rodrigo, 10 de junio era de 1410, año de 1372. Ibídem. Don Garci Fernández envió a la villa a su escudero Juan Alvarez para que en su nombre y a través del poder que le habia dado tomase posesión de ella. Gradefes, 24 de junio era de 1410, año de 1372. Ibidem.

82 Carta del concejo dada en Fuenteguinaldo el 18 de junio de la era de 1410, año de 1372. Ibidem.

a3 Ciudad Rodrigo 19 y 22 de junio de la era de 1410, año de 1372 .

${ }_{84}$ El 7 de enero de 1398 dieron poderes a varias personas para que otorgasen una sentencia sobre sus debates en un plazo de 30 días. A pesar de los esfuerzos y de las demandas presentadas por los vasallos, especialmente sobre robos de ganado y trigo, los jueces no pronunciaron ninguna sentencia. 7 de enero de 1398. AHN. Sección de Osuna, legajo 1.840, $n^{\circ} 1$.

B5 Por un acto público realizado en Ayuela el 25 de noviembre de dicho año se sometieron al juicio del Infante don Fernando o en su lugar al de don Gómez Manrique, Adelantado de Castilla, por la parte de don Garci, y del Almirante Alfonso Enríquez por la de don Pedro. AH. Sección de Osuna, legajo 1.840, n² 2. o RAH. Col. Salazar. M-10. Fols. 197-199.

86 Después prestaron pleito-homenaje de que no comerian cosa alguna en los lugares del otro, ni de behetria ni solariegos, sin pagarlo. Así se dice en una cláusula del acuerdo: “... pero sy 
También en los primeros años del siglo XV don Garci llegó a diversos acuerdos con su primo el Adelantado de León Pedro Manrique sobre la herencia de sus antecesores, por la que mantenian diversos pleitos. En 1405 ambos primos se comprometían a no exigirse deudas y acordaron que se heredarían mutuamente en el caso de morir sin herederos varones legítimos ${ }^{87}$. Años después ratificaban este acuerdo y añadian que don Pedro Manrique renunciaba a sus derechos sobre las Martiniegas de la Merindad de Monzón y a los bienes de la herencia de su padre Diego Gómez Manrique y de otros parientes que estaban en manos de don Garci Fernández. También renunciaba a la condena que el Consejo había impuesto a este señor para que le devolviese ciertos bienes muebles que se había llevado de Amusco, así como a recuperar diversas rentas que había cobrado sin licencia. Por su parte, Garci Fernández Manrique renunció a sus derechos sobre Amusco, por lo que le podía corresponder de su padre o cualquier otro pariente, y a las rentas del lugar, aunque se salvaguardaba su derecho a heredar el mayorazgo instituido por el Arzobispo Juan García Manrique y los demás bienes de sus antecesores en el caso de que don Pedro muriese sin sucesores ${ }^{88}$.

\section{b) La concesión del Condado de Castañeda}

Como acabamos de decir más arriba, don Garci Fernández Manrique a raíz de su matrimonio con doña Aldonza Téllez de Castilla entró en posesión de los territorios de Castañeda y Aguilar de Campoo, además de otros bienes diversos. Su deseo de consolidar estas posesiones le llevaron a intentar conseguir la ratificación de las mismas por privilegios reales ${ }^{89}$. En 1420 llegó su oportunidad, porque, gracias a la intervención de Infante don Enrique, su señor y valedor, Juan II hizo merced a don Garci del Condado de Castañeda, aunque según cierto autor lo único que recibió fue la "tenencia» del mismo ${ }^{90}$.

yendo nosotros por nuestro camyno nos fuere forçado de pasar por algunos lugares vuestros... $e$ ovyeremos de comer ay e tomaramos alguna vianda para comer o otra cosa alguna que non partamos dende fasta que lo paguemos en dinero o en buenas prendas que valan el doblo...". También prometían que no tomarian vasallos de behetria ni de encomienda del contrario, bajo pena de mil doblas de oro. Ibidem.

87 Palencia, 12 de abril de 1405. RAH. Col. Salazar. M-1. Fols. 99-100.

88 Valladolid, 13 de abril de 1413. RAH. Col. Salazar. M-1. Fols. 98-98v. Pruebas, pág. 85.

89 Rogelio Pérez Bustamante, Señorio y vasallaje en las Asturias de Santillana (s. XIII-XV), Santander, 1978, pág. 125.

90.28 de octubre de 1420. Véase ibidem, pág. 126 
Don Garci Fernández no tomaria, sin embargo, posesión del condado hasta 1421, al enterarse de que don Alvaro de Luna lo había hecho con su recién concedido señorío de San Esteban ${ }^{91}$. El señor de Castañeda envió a su mujer a la toma de posesión del "condado" ${ }^{92}$, al tiempo que él tomaba título de conde, como refiere algún cronista ${ }^{93}$, pero el rey, que por entonces se había liberado de manos del Infante don Enrique, protector de don Garci, se negó a reconocer a este magnate la posesión y el título que había adquirido, y anuló la merced que le había hecho un año antes, ya que como afirman los cronistas había sido otorgada "contra su voluntad" 94 y "por súplica del Infante Enrique» ${ }^{95}$.

Poco después don Garci, por su implicación en diversos sucesos políticos junto con el Infante don Enrique, sería detenido y sus bienes embargados ${ }^{96}$, hasta que en 1428, tras unos años de prisión, fue liberado y perdonado por el monarca que le confirmó la merced del condado de Castañeda y el título de conde ${ }^{97}$. Don Garci, para dar más seguridad a la

91 Don Garci no tomó posesión, sin embargo, de la villa de Palenzuela que también le habia sido otorgada porque, según dice cierto cronista, sabia que no le recibirian por señor sin consultar al rey. Alvar Garcia DE SAnTAmaria, Crónica de Juan II, (1420-1434), Codoin, tomo XCIX, Madrid, 1891 , pág. 210.

92 Se conservan dos memoriales sobre la toma de posesión, recibimientos, juramentos, y pleitos homenajes de los concejos, vecinos y oficiales, que llevaron a cabo doña Aldonza y un procurador de don Garci, de nombre Juan Garci de León. Relata detalladamente el proceso R. PÉREZ Bustamente, Señorio y vasallaje..., págs. 128-129, notas 29 y 30 .

93 Por ejemplo asi lo narra Alvar GaRcia DE SANTAMAaIA: “... e como la tierra de Castañeda hobiera seido otros tiempos Condado, é se llamara asi Condado de Castañeda, de la tierra tomó Garcia Fernández el título, é acordó de se llamar Conde de Castañeda, la cual posesion tomó por él doña Aldonza, su mujer. Esta era hija de don Juan, Señor de Aguilar, fijo del Conde don Tello..." Crónica de Juan /I (1420-1434), CoDoin, tomo XCIX, pág. 209.

94 Halconero, pág. 7.

95 Refundición, págs. 44-45. Para mayor seguridad el rey envió un Ballestero de Maza a la tierra de Castañeda con cartas en las que prohibia a los lugares y vecinos del condado recibir por señor a don Garci, señalando que en el caso de que ya hubiese sido recibido que no le consintieran usar la jurisdicción ni señorío bajo diversas penas. Sin embargo, ciertas personas "que pensaron facer placer á don Garci Fernández" tomaron las cartas del ballestero y le apalearon. Enterado el rey del agravio que habia sufrido su oficial, decidió ir personalmente a Castañeda a castigar la deshonrosa acción, aunque problemas diversos se lo impidieron momentáneamente. No obstante, poco después se dirigió alli acompañado de Diego Gómez de Sandoval, Adelantado de Castilla, con 1.000 lanzas. Antes de llegar a Aguilar de Campoo envió con cien hombres de armas a Diego Pérez Sarmiento, su Repostero Mayor, y al doctor Pero González de Castillo, Alcalde en su corte y corregidor en Asturias, para que hiciesen justicia y prendiesen a todos los que estuvieran relacionados con el asunto del ballestero. Alvar Garcia de SANTAMaria, Crónica de Juan II, (1420-1434), CODOiN, tomo XCIX, págs. 210 y 219.

96 Fernán PÉREz de GuzMan, Crónica de Juan I/, "Crónicas de los Reyes de Castilla", II, BAE, tomo 68, Madrid, 1953, pág. 417.

97 Según consta en un privilegio rodado de Juan Il otorgado en Segovia el 25 de agosto de 1430, por el que confirma la concesión de la tenencia de Castañeda y del título de conde hecha a 
concesión del monarca, hizo valer los derechos que a la tierra de Castañeda tenía su esposa doña Aldonza Téllez de Castilla. En 1430 otorgó una escritura en la que afirmaba que Juan II le había concedido el condado como herencia del Conde de Tello y del hijo de éste, don Juan Téllez, padre de doña Aldonza, del que ella se declaraba hija legítima y universal heredera ${ }^{98}$. Parece pues que el conde de Castañeda pretendía que en el caso de que él muriese sin descendencia los derechos de doña Aldonza quedasen a salvo.

En virtud de la merced real don Garci tomó posesión del Condado de Castañeda ${ }^{99}$, pero pronto tuvo que enfrentarse con las continuas intromisiones jurisdiccionales de los Corregidores de la Merindad de Asturias de Santillana sobre sus lugares y vasallos ${ }^{100}$. Las quejas del conde impulsaron al rey a otorgar una cédula real en la que ordenaba a los concejos de Castañeda, sus barrios y lugares que no impidieran el ejercicio de la jurisdicción sobre ellos a don Garci. El monarca explicaba entonces que al conde le correspondían 800 vecinos en Castañeda y los lugares más cercanos, pero para mayor certeza de los hechos envió a hacer una pesquisa al Bachiller Juan Sánchez de Peralta, alcalde de la Corte, quien informó al rey que don Garci sólo tenía 776 vasallos. Como faltaban 24 vasallos de los 800 que había recibido de merced el primer conde de Castañeda, el monarca ordenó a Juan Sánchez de Peralta que se los entregara a su

Garci Fernández Manrique en el Real cerca de Peñafiel el 26 de junio de 1429. Archivo de los condes de Castañeda, $n^{\circ} 130$. Publicado por Evaristo Martín de Sandoval y Carmen Travesedo y Colón de CaRvajal en "Garci Fernández Manrique, I Conde de Castañeda", Aitamira, (1975), págs. 79 y ss. También mencionan la merced Alvar Garcia dE SANTAMARía en su Crónica de Juan 1/, (1420-1434), Codoín, vol. C, pág. 79, y Fernán PÉREz de GuzMÁN, Crónica de Juan II, pág. 459. La confirmación provocó la protesta de don Pedro de Velasco, Camarero Mayor de! Rey, quien desde hacía años mantenía pendiente un pleito sobre el señorio de Castañeda por una concesión que le habia hecho Enrique III. El monarca con acuerdo del Condestable, del Almirante y del Adelantado de León Pedro Manrique, decidió compensar de esa pérdida a su Camarero con la concesión de 70.000 maravedies de juro de heredad, merced que fue aceptada por Pedro de Velasco. Relata los hechos Fernán PÉREZ DE GuZMáN, Crónica de Juan II, pág. 461.

98 Documentos dados en Madrid, el 25 de febrero de 1430. Archivo de los condes de Castañeda, ñ 129. Publicado por E. Martín de Sandoval y C. Travesedo, en "Garci Fernández...", págs. 88-91. También puede consultarse este documento en RAH. Col. Salazar. M2. Fols. 301-304.

99 Don Garci se trasladó a Castañeda para tomar posesión personalmente de cada uno de los concejos que integraban el condado, en un recorrido que duró desde el 2 de noviembre al 13 de diciembre de 1429. Archivo de los condes de Castañeda, $n^{\circ} 128$. R. Pérez Bustamante ha publicado el documento en el que se recogen los juramentos y recibimientos que dichos lugares hicieron al conde en su libro Sociedad, Economia, Fiscalidad y Gobierno en las Asturias de Santillana (s. XIII-XV), Santander, 1979. págs. 101-102.

100 lbidem, pág. 103. 
hijo don Juan Manrique, que por entonces ya había sucedido a su padre en el mayorazgo ${ }^{101}$.

c) El reparto del patrimonio a la muerte del primer conde de Castañeda. Evolución del señorío con el ll Conde de Castañeda Juan Manrique

Desde que fue perdonado por Juan II, don Garci Fernández Manrique permaneció fiel al rey y a su valido don Alvaro de Luna, con quien estrechó relaciones, por lo que el monarca le concedió en 1429 la villa de Galisteo ${ }^{102}$, confiscada a los Infantes de Aragón, le prometió la de Cea ${ }^{103}$, y le otorgó el oficio de Canciller Mayor. En mayo de 1436 fallecía en Alcalá de Henares el Conde de Castañeda. En su testamento, otorgado el día 16, fundaba dos mayorazgos para sus hijos Juan y Gabriel Manrique ${ }^{104}$.

A Juan, el primogénito, como su sucesor, le dejaba el Condado de Castañeda con todas sus villas, lugares, justicia civil y criminal, y con sus derechos correspondientes, el título de Conde y su oficio de Canciller Mayor. Además de las villas de Isar, Villanueva del Río, Villalumbroso, Soto y Segura con sus respectivas casas fuertes. También le legaba Cea, villa que el monarca le había prometido, o en su defecto cualquier otra merced similar que el rey le concediese. Además pedía a la Condesa de Castañeda que le diese la villa de Aguilar de Campoo y su tierra, Bricia, Santa Gadea y Villasirga - hoy Villalcázar de Sirga-, villa esta última que la condesa había heredado de su madre. Aparte le dejaba también todas sus rentas, juros y quitaciones.

A su segundo hijo, el Comendador de Castilla don Gabriel Manrique, le legaba el Conde por mayorazgo sus villas de Galisteo y Fuenteguinaldo con sus términos, derechos y jurisdicción. Más tarde le añadiría en otra cláusula el lugar de Villalumbroso, que le quitaba, por tanto, a su primogénito, aunque éste después lo recuperó. Estos bienes serían el origen del señorío de los Condes de Osorno.

101 Valladolid, 8 de junio de 1437. RAH. Col. Salazar. M-123. Fols. 77v-81.

102 Según consta en el privilegio dado en Ciudad Rodrigo el 2 de octubre de 1432. M-123. Fols. 8v-12. Pruebas, págs. 81-84.

103 En su testamento asi lo reconoce don Garci, que se la deja en herencia a su esposa para que después pasase a su hijo mayor. Testamento otorgado el 16 de mayo de 1436. RAH. Col. Salazar. M-123. Fols. 1-8.

104 Don Garci repartia los bienes en virtud de la autorización que para ello le había concedido en 1432 Juan Il. Albalá dado el 22 de agosto de 1432. RAH. Col. Salazar. M-123. Fols. 74-77v. El testamento fue otorgado el 16 de mayo de 1436. RAH. Col. Salazar. M-123. Fols. 1-8. 
El /l conde de Castañeda don Juan Manrique ( $i-1493)$ mostró inmediatamente su desacuerdo con las disposiciones testamentarias de su padre y trató de recuperar Fuenteguinaldo. Ante las disputas de los hermanos su madre, la Condesa de Castañeda doña Aldonza, decidió intervenir para aquietar los ánimos y logró que ambos señores se comprometieran a aceptar la sentencia que al respecto dieran ella misma y el Condestable don Alvaro de Luna ${ }^{105}$. Un mes después este caballero sin la Condesa, que estaba ausente de la Corte, determinó que Fuenteguinaldo pasase al Conde de Castañeda y que don Gabriel recibiese a cambio 200.000 mil maravedies ${ }^{106}$.

Satisfecho por el resultado de la sentencia, don Juan Manrique continuó el proceso de consolidación del patrimonio que iniciara su padre. Así en 1438 llegaba a un acuerdo con el Abad de Castañeda en el que se reconocían ciertas iglesias que correspondian al condado y al señorío de los Manrique ${ }^{107}$, y se enfrentaba con éxito con los vasallos que tenía concedidos en el Valle de Toranzo, que alegaban ser de behetría y tener derecho a elegir a su señor ${ }^{108}$. El Conde de Castañeda ganaría este engorroso pleito ${ }^{109}$, y el 7 de febrero de 1439 Juan II le confirmaba de nuevo la merced de los 800 vasallos.

El abandono del partido de los Infantes de Aragón y su adhesión al del valido regio don Alvaro de Luna, así como su colaboración en la toma de Peñafiel y otras villas a los nobles rebeldes, le valieron a Juan Manrique en 1444 la concesión real de los valles de Toranzo, Iguña, San Vicente y Rionansa en las Asturias de Santillana ${ }^{110}$. Juan II le compensaba con esta

105 Madrid, 12 de junio de 1436. Archivo de los Condes de Castañeda, n 123. Rogelio PÉREZ Bustamante, Sociedad.... pág. 105.

106 Madrid, 22 de julio de 1436. RAH. Col. Salazar, M-123, fols. 101-106.

107 La concordia tuvo lugar el 10 de diciembre de 1438. Archivo de los Condes de Castañeda, ñ 13.3. Datos tomados de Rogelio Pérez Bustamante, Sociedad..., pág. 104.

108 En nombre del concejo y hombres buenos de Toranzo protestó Ruy González de Villasevil alegando que eran vecinos de behetria y naturales de los Ceballos. Esta familia, por su parte, a través de Juan Diaz de Ceballos también reclamó sus derechos. A las protestas de los vecinos y de los Ceballos se sumaron las de don Iñigo López de Mendoza que afirmaba tener también ciertos derechos, porque decia que habia comprado esos vasallos a Sancho Ruiz de Villegas. $R$. Perez Bustamante, Señorio y vasallaje..., págs. 140-141, que toma los datos de M. Escagedo Salmón, La Casa de la Vega. Comentarios a las Behetrias Montañosas y el pleito de los valles. Torrelavega, 1917, pág. 206.

${ }_{109}$ El pleito comenzó en Arévalo el 8 de febrero de 1438. El caso fue encomendado al doctor Fernando Diaz de Toledo y la sentencia, que fue favorable al conde de Castañeda, se dio el 31 de diciembre de 1438 en Madrigal. A.C. Castañeda, $n^{\circ}$ 133. Referencia tomada de Rogelio PÉrez. Bustamante, Sociedad..., pág. 107

110 En un albalá dado el 28 de agosto de 144. Casa de Lara, tomo I, pág. 514. 
merced el no haberle otorgado la villa de Cea que había prometido a su padre. Don Juan Manrique desde entonces se mantuvo extremadamente fiel al monarca y a su valido, en cuya casa vivía, lo que le valió en 1449 la concesión regia de las Merindades de Peñarrubia y Peñamellera, y la confirmación de los valles antes citados ${ }^{111}$.

Un año antes, en 1448, don Juan Manrique había vuelto a enfrentarse con su hermano Gabriel, Conde de Osorno, en esta ocasión por la herencia de su madre doña Aldonza, fallecida ese año. Ésta señora en su testamento otorgado en 1443, cumpliendo la que fuera voluntad de su marido el I Conde de Castañeda, había dejado a Juan Aguilar de Campoo, Santa Gadea, Bricia, y otros bienes diversos, además de sus derechos sobre Liébana, Pernia y Campo de Suso, territorios por los que los Condes de Castañeda mantenian duros pleitos con los sucescres de doña Leonor de la Vega, madre de doña Aldonza ${ }^{112}$. Ésta, no obstante lo dispuesto por su esposo, decidió dejar a su segundo hijo Gabriel Manrique San Martín del Monte y Villasirga -hoy Villalcázar de Sirga-, posesiones que le habian correspondido de la herencia de su madre, violando con esta cláusula los deseos de su marido que le había rogado en su testamento que también estos bienes fueran para el primogénito ${ }^{113}$. Con el fin de solucionar amistosamente los pleitos, los dos hermanos se sometieron a la sentencia de unos jueces árbitros que debió de ser favorable a don Gabriel, pues este conservó los señoríos objeto de litigio ${ }^{114}$.

Don Juan Manrique continuó ampliando su patrimonio mediante compras: en 1461 adquirió una parte del Condado de Buelna ${ }^{115}$, adquisición 516.

111 Privilegio dado en Tordesillas el 21 de noviembre de 1449. Casa de Lara, tomo I, pág

112 Doña Aldonza se consideraba legítima heredera de los bienes de su padre Juan Téllez, a quien Enrique II mediante un privilegio real, dado el 18 de febrero de 1371 , le había conferido los señorios de su padre el conde don Tello, Castañeda y Aguilar de Campoo, además de Liébana, Pernia y Campo de Suso. Juan Téllez contrajo matrimonio con doña Leonor de la Vega, pero falleció prematuramente, lo mismo que su primogénito Juan el Mozo. Enrique lli en 1395 concedió a su magnate Diego Hurtado de Mendoza, con quien doña Leonor de la Vega casaria en segundas nupcias, Liébana, Pernía y Campo de Suso, lo que dio lugar a un enfrentamiento entre éstos y doña Aldonza y su marido Garci Fernández Manrique, señores de Castañeda y Aguilar, que pretendian tener derecho a los referidos bienes. Sobre los pleitos entre los Manrique y los sucesores de doña Leonor de la Vega, pueden consultarse entre otros los trabajos de M. ESCAGEDO SALMÓN y de Rogelio Pérez Bustamante ya citados.

113 Testamento otorgado en el Monasterio de San Benito de Valladolid, el 6 de septiembre de 1443. RAH. Col. Salazar. M-1. Fols. 113v-114v. También en AHN. Sección de Clero. Libros. $n^{0}$ 16.797.

114 Carrión de los Condes, 8 de junio de 1448. RAH. Col. Salazar. M-123. Fols. 105-110.

115 Tras la desaparición de Pero Niño, Conde de Buelna, sin heredero varón, pretendió sin éxito el condado su sobrino Alonso Niño, Merino Mayor de Valladolid, pero Enrique IV ordenó que 
que debió hacer por la proximidad a sus posesiones, y en 1480 la Honor de Sedano y sus lugares comprados a don Lope de Silva, hijo de los condes de Cifuentes por 2.756.715 maravedies ${ }^{116}$. También compró el conde Manquillos a Pedro Ruiz de Reinosa, señor de Autillo, que le vendió el lugar en nombre de doña Maria de Herrera su mujer y propietaria. Asimismo se hizo con el dominio completo del lugar de Piña ${ }^{117}$ y de Abia.

En 1484 el Conde de Castañeda fundaba con su rico patrimonio dos mayorazgos para sus hijos que ponen de manifiesto el extraordinario acopio de bienes que había hecho ${ }^{118}$. En el del primogénito, de nombre Garci Fernández Manrique, se incluian los bienes que había heredado de sus padres: el Condado de Castañeda; el lugar de Isar; las villas de Villanueva del Río, Cartes con sus aldeas y barrios, y Aguilar de Campoo — „de que vos he intitulado e fecho Marqués" ${ }^{119}$, decía el conde refiriéndose a su hijo-, con su fortaleza y todos los lugares de su alfoz, rentas y jurisdicción. También estaban en el mayorazgo las mercedes que le había hecho el rey: los valles de Toranzo, Iguña, Buelna, San Vicente y Reinansa, y las Merindades de Peñarrubia y Peñamellera. A todo esto añadía lo que él había adquirido por compras, trueques u otras vías, según reconoce: Piña, Abia, Santillana del Campo, Val de Lamasón, con todos los derechos y la jurisdicción, La Honor de Sedano, Los Alfoces de Arenas y Orbaneja, el lugar de Ruero con el Patronazgo de San Martín de Elines y las Martiniegas de diversos lugares. Además dejaba a su primogénito el oficio de Merino de la Merindad de Campoo —el de Canciller Mayor se lo había

fuera entregado a la hija del conde doña María Niño, que estaba casada con Garcia de Herrera, señor de Pedraza. Ambos procedieron a la venta del condado: una parte fue comprada, como hemos dicho, por el conde de Castañeda y la otra por las monjas del Monasterio de Santa Clara de Valladolid. 11 de junio de 1461. Archivo de los Duques de Frías. Legajo 113, $n^{\circ} 6$. Referencia tomada del Inveritario..., de Pilar León Tello y Ma Teresa Peña MARAzUela.

116 Luis Salazar y Castro, Historia Genealógica de la Casa de Silva, Madrid, 1685, Libro III, pág. 277.

117 En Piña el conde de Castañeda se apropió de diversas heredades y casas fuertes de doña Constanza de Herrera. El hijo de esta señora, Alvaro de Herrera, se quejó repetidamente a los monarcas, pero a pesar de las órdenes para devolver los bienes usurpados el Conde de Castañeda se negó a hacerlo. Biblioteca Nacional de Madrid. Manuscrito Reservado n²26.

118 Por una escritura dada en su villa de Piña el 26 de febrero de 1484. RAH. Col. Salazar. M123. Fols. 84-93. Pruebas, págs. 132-135. Los Reyes Católicos le habian dado años antes licencia para fundar un mayorazgo en su primogénito Garci Fernández Manrique. Toledo, 20 de junio de 1480. A.G. Simancas. Sello. Fol. 3.

119 El Conde de Castañeda habia conseguido que los Reyes Católicos le concedieran para su hijo el título de Marqués de Aguilar de Campoo, y desde entonces tanto don Garci como sus sucesores antepondrian este título al de Condes de Castañeda. Alonso LÓPEz de HARo, Nobiliario..., fol. 178 . 
renunciado años antes-, los vasallos y rentas que poseía en dicha merindad y todos los maravedies de juro que tenía de los Reyes ${ }^{120}$.

A su segundo hijo llamado Juan como él, el segundo conde de Castañeda le transmitía por mayorazgo: Fuenteguinaldo, con sus rentas, derechos y jurisdicción civil y criminal, y el lugar de Villalumbroso, que él había heredado de su padre. Aparte le legaba los lugares de Revenga, Villarmentero y Villatoquite con sus casas fuertes y llanas, su jurisdicción y sus rentas ${ }^{121}$. Estos bienes serían la base del señorio de Fuenteguinaldo, del que nos ocuparemos después.

\section{El señorio de los Condes de Osorno}

\section{a) La formación del señorio}

El señorío de los Condes de Osorno nació con el mayorazgo que fundó en 1436 el I conde de Castañeda Garci Fernández Manrique, para su segundo hijo Gabriel Manrique (i-1482), entonces Comendador Mayor de Castilla en la Orden de Santiago. El citado mayorazgo incluía las villas de Galisteo y Fuenteguinaldo con todos sus derechos y la jurisdicción civil y criminal, y Villalumbroso, lugar que don Garci en una de las últimas cláusulas de su testamento añadió al mismo en un cambio de opinión, ya que anteriormente se lo había dejado a su primogénito Juan Manrique, el II conde de Castañeda ${ }^{122}$. Sin embargo, éste, como ya tuvimos ocasión de ver al ocuparnos de su señorío, recuperó Villalumbroso y Fuenteguinaldo tras un acuerdo con su hermano Gabriel.

120 Aparte le dejaba diversas casas en Carrión; los vasallos de Villanueva del Río y todo lo que heredó alıí de su hermana Doña Beatriz Manrique; los vasallos de Quintanilla de Onsona; los vasallos y pan de renta que compró en Campos a Gutierre de Quejada, y cierto Pan de renta de Villamarzo y Castellanos.

121 Estas fundaciones las aprobó el conde en su testamento otorgado en 1486. Después ante Rodrigo Alvarez de Bobadilla, su secretario, otorgó un codicilo en el que refería su temor a que el Marqués de Aguilar disputase a su hermano los bienes que le había dejado, por ello ordenaba que si intentaba privarle de los mismos perdiera la mejoria que a su favor habia hecho en el mayorazgo y que ésta pasase a don Juan Manrique. Además fijaba una pena de 10.000 doblas de oro castellano para cualquiera de sus dos herederos que violara alguna cláusula del mayorazgo. Revenga, 27 de febrero de 1486. Casa de Lara, tomo 1, pág. 521. Para mayor prevención en 1487 volvió a otorgar otra escritura en la que rogaba a los monarcas que obligasen al Marqués a entregar a su hermano la fortaleza de Villalumbroso si éste no queria hacerlo, en un afán paterno por proteger los legados de su segundogénito. Monasterio de Santa Clara de Aguilar de Campoo, 11 de noviembre de 1487. Pruebas, pág. 135-136.

122 Testamento dado en Alcalá de Henares el 16 de mayo de 1436. RAH. Col. Salazar. M123. Fols. 1-8. 
Galisteo, como dijimos, la habia recibido por merced regia Garcia Fernández Manrique en 1429 tras el despojo de bienes sufrido por los Infantes de Aragón ${ }^{123}$. Esta villa, ubicada en la actual provincia de Cáceres, estaba muy alejada del núcleo central del mayorazgo de los Condes de Castañeda, situado principalmente en tierras palentinas y en Santander. Galisteo y su tierra formaban un rico señorio, pues en ella se incluían los lugares de Pozuelo, Montehermoso, El Guijo, Aceituna, Holguera, Riolobos, Malpartida, Valdeobispo, Carcaboso, Aldehuela, Dehesas del Rincón, Navasmojadas y Casillas ${ }^{124}$. En cuanto a Fuenteguinaldo, villa próxima a Ciudad Rodrigo, como ya vimos, había sido donada por Enrique II en 1370 al padre y homónimo del I Conde de Casteñeda, el señor de Isar Garci Fernández Manrique ${ }^{125}$.

Una de las villas más importantes del señorío de Gabriel Manrique sería Osorno, posesión que doña Mencía Dávalos, su primera esposa, aportó al matrimonio, pues sobre ella se erigiría su título condal ${ }^{126}$. La villa palentina había pertenecido al padre de doña Mencía, el Condestable Ruy López Dávalos, pero fue confiscada junto con sus restantes bienes por orden regia tras su caída en desgracia. El rey concedió entonces Osorno a Don Diego Gómez de Sandoval, Conde de Castro, por lo que la villa pasaría a formar parte con otras doce del condado de Castro concedido por Juan II a Don Diego el 11 de abril de $1426{ }^{127}$. Gabriel Manrique intentó hacer valer los derechos de su esposa sobre Osorno e inició un largo contencioso con el Conde de Castro que ganó finalmente, porque el día 30 de agosto el monarca le concedía título de conde sobre dicha villa en premio a sus servicios políticos, especialmente por su apoyo en la elección de don Alvaro de Luna como Maestre de Santiago ${ }^{128}$.

El señorío del I Conde de Osorno se incrementó con los bienes vinculados por mayorazgo que le dejó en herencia su madre doña Aldonza de

123 Privilegio de Juan II por el que confirma un albalá dado en Roa el 4 de marzo de 1429 en el que donaba al Conde de Castañeda la villa de Galisteo. Ciudad Rodrigo, 2 de octubre de 1432. RA4. Col. Salazar. M-123. Fols. 8-12. Pruebas, págs. 81-84.

124 Según se mencionan en diversos pleitos de los condes de Osorno con la Tierra de Galisteo. A.G. Simancas. Cámara de Castilla. Pueblos, legajo 8. También se mencionan en el mayorazgo que fundó el III Conde de Osorno Garci Fernández Manrique en febrero de 1544. A.G. Simancas. Contaduría de Mercedes. Juros. Legajo 5. fol. 83.

125 Privilegio Rodado dado en Alcalá de Henares el 13 de mayo era de 1408, año 1370. RAH.

Salazar. M-123. Fols. 12-19v.

126 Gonzalo FERNANDEZ DE OVIEDO, Batallas y Quinquagenas, pág. 312.

127 Alfonso Franco SILVA, «El linaje Sandoval y el señorío de Lerma en el siglo XV». Actas I Congreso de $H^{a}$ de Castilla y León. I. Edad Media, Burgos, 1983, págs. 138-139.

128 Alonso López DE HARO, Nobiliario..., tomo I, pág. 320. 
la Vega en 1443: Villasirga (hoy Villalcázar de Sirga), con todas sus heredades, fortalezas y todos sus derechos, y el lugar de San Martín del Monte, posesiones que esta señora habia heredado de su madre doña Leonor de la Vega junto con otros bienes muebles diversos ${ }^{129}$.

En 1474, durante las disputas por el Maestrazgo de Santiago, don Gabriel Manrique secuestró al Marqués de Villena Diego López Pacheco, uno de los pretendientes a la preciada dignidad, aunque terminó liberándole a cambio de la entrega de Maderuelo ${ }^{130}$, villa que por diversas circunstancias los Condes de Osorno no pudieron conservar, pero que don Gabriel incluyó en su testamento. Aparte de esta adquisición frustrada, Gabriel Manrique añadió a su señorio las villas de Gama y Ordejón, con sus fortalezas, casas, derechos y jurisdicción civil y criminal, además de los lugares de Villanueva y Cigoñera, heredad esta última que compró el Conde al Monasterio de San Francisco de Carrión por 100.000 maravedies en $1461^{131}$. Todo esto, más la mitad de Maderuelo (la otra mitad se la dejaba mientras viviese a su esposa la condesa doña Aldonza de Vivero), las casas de Valladolid y las de Carrión con todas "sus pertenencias" ${ }^{132}$, y lo que habia heredado de su padre se lo dejaba por mayorazgo en su testamento otorgado en 1482 a su primogénito y sucesor, Pedro Manrique.

\section{b) Evolución del señorio}

Con los siguientes titulares, el señorio creció gracias a las compras y a los bienes aportados por las esposas de los mismos. El // Conde de Osorno Pedro Manrique ( $i-1515)$ adquirió el lugar de Bayala, posesión de Pedro de Guevara, señor de Casa de Olmos ${ }^{133}$ y Villameriel, lugar que le

129 Testamento otorgado en el Monasterio de San Benito de Valladolid, el 6 de septiembre de 1443. RAH. Col. Salazar. M-1. Fols. 113v-114v. También en AHN. Sección de Clero. Libros. $n^{\circ}$ 16.797.

${ }_{130}$ Alonso de PALENCIA acusaba al Conde de haberse sometido a los "pactos más vergonzosos". Crónica de Enrique IV. Traducción castellana de don Antonio Paz y Meliá, BAE. 3 vols. Madrid, 1973-1975, vol. II, pág. 148.

13111 de noviembre de 1461. Tomó posesión el día 12. AHN. Sección de Osuna. Legajo $1.827, n^{9} 4$. Esta propiedad había sido dada al monasterio por Gonzato Ruiz de la Vega y su esposa Mencía de Toledo a cambio de ciertas misas, por lo que sus herederos, considerándose dañados en sus derechos, pusieron pleito al conde de Osorno, aunque la demanda no tuvo éxito. Carrión, 15 de junio de 1463. RAH. Col. Salazar. M-19. Fols. 193-194 v.

132 Valladolid, 25 de marzo de 1482. RAH. Col. Salazar. M-123. Fols. 99-100v

${ }_{133}$ Su madre le prestó para la compra 300.000 maravedies, según consta en su testamento. Villasirga, 11 de noviembre de 1509. AHN. Sección de Clero. Legajo 1.016. 
vendió en 1499 Alonso Muñoz de Castañeda, señor de Hormaza ${ }^{134}$. Asimismo compró a este caballero en 1509 los lugares de Villavieco, cerca de Villasirga, con la jurisdicción civil y criminal, y el de Diezma por 1.140.000 maravedíes ${ }^{135}$. Su madre Aldonza de Vivero también le dejó por mayorazgo en su testamento, gracias a una licencia real ${ }^{136}$, su dote y sus arras, que incluían lo que le pertenecía en Villasirga, en San Martín del Monte, Población del Soto y Bayala, así como otros vasallos y casas en varios lugares que su marido le había entregado con la condición de dejárselos después a Pedro Manrique, su heredero.

El III Conde de Osorno Garci Fernández Manrique (¿-1546), a la rica herencia que habría de heredar de su padre en 1515, incorporó unos años antes al señorío familiar las posesiones que había aportado su primera esposa Juana Enríquez al matrimonio: las villas de Baños, Grañeras, Hito, Vega de Ruiponce y otros bienes que serían causa de numerosos pleitos para los condes de Osorno. Primeramente al morir Juana el mismo año de la boda, su abuela Beatriz de Figueroa exigió a Garci Fernández Manrique la devolución de la dote y le acusó de falsificar el testamento de su nieta ${ }^{137}$, en el que ésta le nombraba heredero de sus bienes. El litigio por la herencia de doña Juana Enríquez no se solucionó en vida de los protagonistas y continuó con sus sucesores ${ }^{138}$, ya que el III Conde de Osorno se los dejó en herencia a su primogénito y heredero ${ }^{139}$.

También el Almirante don Fadrique Enríquez entabló un pleito con don Garci por Vega de Ruiponce, ya que esta villa se la habia dejado su abuelo a Francisco Enríquez - padre de la fallecida esposa del conde de Osorno doña Juana-, por mayorazgo para sus descendientes varones. Como este señor no tenía más hijos que doña Juana, en 1491 el Almirante autorizó a su tío para que esta señora, aun siendo mujer, pudiera heredar Vega de Ruiponce y renunció a sus derechos sobre la misma. Sin embargo, al morir doña Juana sin sucesión, don Fadrique Enríquez exigió al conde de Osorno la devolución de la villa y de 20.000 maravedíes de juro

134 Madrid, 24 de mayo de 1499. Pruebas, pág. 163.

135 Osorno, 16 de junio de 1509. Casa de Lara, tomo I, pág.

13.6 Dada en Valladolid, el 14 de septiembre de 1508. A.G. Simancas. Contaduria de Mercedes. Juros, legajo 53. fol. 16. Testamento dado en Villasirga, 11 de noviembre de 1509. AHN. Sección de Clero. Legajo 1.016.

137 Algunos pormenores de este pleito se narran en una carta del conde de Osorno dirigida a la Reina. Medina del Campo, 11 de mayo de 1504. A.G. Simancas. Cámara de Castilla. Personas. Legajo 16.

138 En 1552 llegaron a un convenio el IV conde de Osorno y los herederos de Beatriz de Figueroa. Casa de la Reina, 9 de junio de 1552. RAH. Col. Salazar. M-14. Fols. 125-134v.

139 A.G. Simancas. Contaduría de Mercedes. Juros. Legajo 5. fol. 83. 
que Francisco Enríquez había dejado también a su hija. Don Garci Fernández Manrique se negó a entregarle Vega de Ruiponce alegando que su esposa y él habían hecho muchas mejoras en ella. En 1509 para evitar mayores discordias Fernando el Católico decidió intervenir, puso la villa en manos de Juan Dávila, su Repostero, y en su papel de árbitro sentenció que los 20.000 maravedies de juro fueran para don Garci y Vega de Ruiponce para el Almirante don Fadrique, aunque éste debía pagar al conde de Osorno 550.000 maravedies en tres años por las mejoras que había hecho en la villa. Aparte, y quizás como compensación, Fernando el Católico concedió al Conde de Osorno otros 150.000 maravedies ${ }^{140}$.

Por último, don Garci Fernández tuvo también algunos problemas para conservar Baños en su señorío, villa también incluida en la herencia de su esposa doña Juana Enriquez. Baños había pertenecido al Adelantado de León Pedro Manrique desde que el Monasterio de San Isidro se la entregara a cambio de un censo anual de 36 florines de oro, renta que don Pedro situó sobre Amusco. El Adelantado dejó Baños a su hijo Fadrique Manrique, quien a su vez legó esta villa a su hija Elvira Manrique, madre de doña Juana Enríquez, la esposa del conde de Osorno. El nieto del Adelantado de León, el Duque de Nájera Pedro Manrique, se negó a seguir pagando el censo en su villa de Amusco, pues al fin y al cabo Baños ya no pertenecía a su familia, y ganó una sentencia que le liberaba del tributo. El Monasterio de San Isidro exigió entonces la devolución de la villa, pero el conde de Osorno decidió hacerse cargo del censo y pudo seguir poseyendo Baños ${ }^{141}$.

Don Garci Fernández Manrique adquirió a lo largo de su vida otros bienes fuera ya de nuestro marco cronológico de estudio, y dos años antes de su muerte en 1544 dividió su patrimonio en dos mayorazgos, uno para el primogénito con los principales bienes y otro para su segundo hijo Alonso ${ }^{142}$.

\section{LOS PEQUEÑOS SEÑORIOS}

\section{El señorio de Valdezcaray}

\section{a) Núcleo y expansión}

En 1440 el Adelantado de León Pedro Manrique fundó mayorazgo en su hijo del mismo nombre con Anguiano - villa que como vimos había

\footnotetext{
140 Sentencia dada en Valladolid, el 19 de septiembre de 1509. Pruebas, pág. 245 y ss.

141 Valladolid, 8 de enero de 1510. RAH. Col. Salazar. M-6. Fols. 126-128.

142 A.G. Simancas. Contaduría de Mercedes. Juros. Legajo 5. fol. 83.
} 
recuperado para su familia-, lo que tenía en Ezcaray y sus alrededores, 10 lanzas del rey y 5.000 maravedíes de juro de heredad ${ }^{143}$. Era el tercer mayorazgo de los seis que instituyó el Adelantado en su testamento. Don Pedro y sus sucesores, conocidos en la época como señores de "Valdezcaray", continuaron compartiendo con los Leiva el señorio en Ezcaray ${ }^{144}$ y su tierra. Por ello al igual que sus predecesores tuvieron que hacer frente a continuas disputas, muertes y todo tipo de violencias, así como a largos pleitos entre ambas casas, hasta que a finales del siglo XV los Manrique se hicieron con el dominio completo de la villa ${ }^{145}$.

Al patrimonio inicial que había heredado de su padre el Adelantado, el I señor de Valdezcaray Don Pedro Manrique $(i-1483)$ no consiguió añadir muchos más bienes. Su escaso protagonismo político y social por su condición de segundón no le dió demasiadas oportunidades para ello. El que fuera Aposentador Mayor de los Reyes Católicos fundó un mayorazgo con licencia regia en 1478 a favor de su hijo del mismo nombre y de sus sucesores. En dicha escritura don Pedro incluía: la parte que tenía en Ezcaray, Zorraquín y Valgañón; el lugar de Santurde con su casa fuerte ${ }^{146}$; la parte que tenia en Pradilla, aldea de Ezcaray; Anguiano; Villanueva del Conde y Ventosa, por lo que estas dos villas fueron sus adquisiciones más importantes, aunque ignoramos por qué vías se hizo con ellas ${ }^{147}$.

Después de fundar mayorazgo, don Pedro Manrique adquirió las tercias de Ezcaray gracias a la renuncia que le hizo su sobrino Sancho de Velasco en 1481, a quien los Reyes Católicos en las declaratorias de 1480 habian ordenado que dejase dichas rentas. En virtud de la renuncia se

143 Testamento dado en Valladolid el 20 de septiembre de 1440 . RAH. Col. Salazar. M-2. Fols. 83-93. Pruebas, pág. 256-261.

144 Algunos datos muy generales sobre la villa en FR. José GARcia dE SAN LORENZO MÁRTIR. Ezcaray: su historia, Logroño, 1959.

${ }_{145}$ Los Leiva entregaron su parte de Ezcaray a cambio de otros bienes en un acuerdo suscrito por ambas partes en Salamanca el 9 de enero de 1489 y confirmado en Santo Domingo de la Calzada el 22 de abril de 1507. A.G. Simancas. Diversos de Castilla, legajo 40, fols. 23. Los pormenores de los pleitos entre ambas casas en la tesis doctoral inédita de Rosa Mํ MONTERO TEJADA, Los Manrique: linaje noble..., tomo I, págs. $160-163$ y 506-512.

${ }_{146}$ Todo parece indicar que Santurde se lo habia dejado en herencia su madre, ya que no se mencionaba en el testamento de su padre el Adelantado de León don Pedro Manrique, aunque podía estar incluido con los otros bienes en la ambigua referencia de que le dejaba todo to que tenia en Ezcaray. El Adelantado había entregado este lugar y otras villas a su mujer Leonor de Castilia en compensación por ciertos bienes que le había vendido y por cargos diversos que tenía de ella, con la condición de que a su muerte pasasen a sus herederos. Toro, 13 de abril de 1427. RAH. Col. Salazar. M-1. Fol. 101.

${ }_{147}$ Todos estos bienes con sus respectivas casas, fortalezas y jurisdicción se citan en la fundación de mayorazgo hecha en Santurde el 20 de enero de 1478. RAH. Col. Salazar. M-43. Fols. $276-289 v$. 
despachó un privilegio a favor de don Pedro en Córdoba el 20 de junio de $1482^{148}$.

\section{b) La desafortunada gestión del señorio por el II señor de Valdezcaray}

El II señor de "Valdezcaray", también llamado Pedro Manrique ( $i$ 1520), no solo no aumentó el patrimonio paterno, sino que casi llegó a enajenarlo por completo, y únicamente la intervención regia logró sacar a flote la maltrecha situación económica de don Pedro y su familia. Nada más acceder a su herencia comenzó a dilapidarla, ya que en 1487 vendia el lugar de Pradilla a Juan Fernández de Mansilla ${ }^{149}$, y también las tercias de Ezcaray a su hermanastro Bernabe Manrique de Luna y a su mujer Catalina de Toledo, por 120.000 maravedíes de la moneda corriente ${ }^{150}$.

También perdería algunos años después Anguiano, porque el Monasterio de Valvanera, su último poseedor hasta que el Adelantado Pedro Manrique se hizo con la villa, decidió recuperarla — con todos sus derechos, la jurisdicción civil y criminal, la Iglesia de Santa María de las Cuevas que estaba dentro de la misma, un palacio y otros bienes varios-, al tener noticia de que don Pedro se la habia entregado a Juan de Leiva en virtud de ciertos acuerdos entre ambos nobles. En 1502 el Monasterio ganó el pleito que habia iniciado contra don Juan de Leiva y Pedro Manrique y éstos fueron condenados a entregarle la villa, aunque apelaron la sentencia. Don Pedro recurrió incluso a la ayuda de su primo y homónimo el Duque de Nájera, quien, como pariente poderoso y alegando también ciertos derechos suyos, continuó con la demanda. Todos los esfuerzos fueron vanos, porque en 1506 se confirmó la primera sentencia, aunque se añadió que el Monasterio pagase a don Pedro Manrique y a don Juan de Leiva los gastos que habían hecho en los edificios y mejoras de Anguiano ${ }^{151}$. A pesar de perder la villa, don Pedro siguió gozando de

\footnotetext{
148 La renuncia se realizó en Valladolid el 13 de abril de 1481. RAH. Col. Salazar. M-45. Fol. $216 \mathrm{v}$.

149 Según consta en un seguro que recibió este señor. Burgos, 16 de agosto de 1487. A.G. Simancas. Sello. Fol. 37.

150 La venta se realizó en Ezcaray, el 25 de mayo de 1496. RAH. Col. Salazar. M-8. Fols. 121-123v.

151 Sentencia dada en Valladolid el 28 de abril de 1506. RAH. Col. Salazar. M-8. Fols. 177v179. El pleito continuó unos años porque el Monasterio pedia a la Reina en 1510 que se le diese el proceso sobre la villa de Anguiano, ya que lo necesitaba para enviarlo a la corte romana "para se defender de Pedro Manrique» Madrid, 23 de julio de 1510. A.G. Simancas. Cámara de Castilla. Pueblos. Legajo 2. Fol. 20.
} 
sus alcabalas y tercias como sus predecesores, según constaba en una carta del rey otorgada en 1518 para sus contadores ${ }^{152}$.

También estuvo a punto de perder el II señor de Valdezcaray el lugar de Santurde, porque lo utilizó como hipoteca en diversos tratos. Finalmente para poder pagar las cuantiosas deudas que había contraído decidió venderlo. Así parece ser que llegó a un acuerdo con su cuñado Pedro Suárez de Figueroa, que había casado con su hermana doña Elvira Manrique, quien compró la villa por 1.500 .000 de maravedíes, aunque al final la venta debió anularse, porque don Pedro conservó Santurde ${ }^{153}$.

Sin embargo, las mayores dificultades para el II señor de Valdezcaray vendrían de la mano de la adquisición y venta de Escamilla. Don Pedro Manrique entabló diversos tratos con doña Contesina de Luna, la segunda esposa de su padre, y con su hermanastro Bernabé Manrique para hacerse cargo del pleito que éstos querían iniciar por la herencia paterna de doña Contesina. El padre de esta señora, don Alvaro de Luna, señor de Carvajales, había intercambiado en 1441 con don Enrique Enríquez sus villas de Carvajales y Alba de Liste _-villa esta última sobre la que este caballero alcanzaría más tarde título de conde- por Escamilla, situada en el Obispado de Sigüenza. Muerto sin sucesión el primogénito de don Alvaro de Luna, otro de sus hijos y homónimo, se apoderó de Escamilla sin tener derecho a ello pues era clérigo, lo que empujó a Doña Contesina a reclamar la herencia de su padre para que pudiera heredarla su hijo Bernabé. Tanto éste como su madre sabían lo costosos que podían llegar a ser los pleitos y por ello decidieron comenzar ciertas gestiones con don Pedro Manrique, II señor de Valdezcaray, para que se hiciese cargo de los mismos a cambio de diversos beneficios.

Tras obtener la pertinente licencia regia ${ }^{154}$, Doña Contesina y Bernabé cedieron al segundo señor de "Valdezcaray» don Pedro Manrique los derechos de esta última sobre Escamilla y Alba de Liste, villa que doña Contesina consideraba que podía demandar basándose en que el intercambio que había hecho su padre en 1441 con Enrique

152 Zaragoza, 19 de octubre de 1518. A.G. Simancas. Mercedes y Privilegios. Legajo 78, fol. 8.

153 La venta fue incluso confirmada por los monarcas, quienes la autorizaron a pesar de ser la villa de mayorazgo. La única condición impuesta por los Reyes era que don Pedro introdujese en el mayorazgo otros tantos vasallos como hubiese en Santurde. Madrid, 16 de marzo de 1495. A.G. Simancas. Sello. fol. 1.

${ }_{154}$ Los Reyes Católicos concedieron licencia a Contesina y Bernabé para poder vender, trocar o enajenar aquellos bienes que les pertenecieran de la herencia de don Alvaro de Luna, muchos de los cuales, según constaba en la citada facultad, estaban ocupados por personas poderosas del reino. Zaragoza, 11 de febrero de 1488. A.G. Simancas. Sello. Fol. 2. 
Enriquez era desigual. Don Pedro a cambio les daba Villanueva del Conde y Ventosa, pero como estos lugares los tenia empeñados por otros tratos suyos con los Leiva, se comprometió a pagarles en cuatro años diversas cantidades que ascendían a 1.800 .000 maravedíes ${ }^{155}$, y les entregó como garantía su villa de Santurde con su fortaleza, rentas y señorío. Durante los cuatro años fijados en el plazo acordaron que doña Contesina y Bernabé Manrique cobraran todas las rentas y derechos de Santurde, lugar que podrian finalmente vender si transcurrido el mismo don Pedro no había pagado lo estipulado. En virtud de estos tratos Bernabé Manrique de Luna tomó posesión del señorío de esta villa logroñesa ${ }^{156}$.

Don Pedro Manrique inició pues, según se hacía constar en el acuerdo antes referido con su madrastra doña Contesina de Luna y su hermanastro Bernabé Manrique, dos pleitos: uno sobre Alba de Liste y otro sobre Escamilla. Sobre la primera villa el señor de Valdezcaray puso una demanda a don Alonso Enríquez de Guzmán, conde de Alba de Liste, para que le diese la equivalencia de lo que valian de más Alba de Liste y Carvajales que Escamilla, aunque don Pedro no tuvo éxito en su demanda.

En cuanto a la villa de Escamilla, que como dijimos la tenía ocupada don Alvaro de Luna, hermano de doña Contesina, la Chancillería de Valladolid dio sentencia favorable a don Pedro, porque siendo clérigo don Alvaro no podía entrar en posesión del mayorazgo paterno ${ }^{157}$. Don Pedro Manrique añadió a sus posesiones en virtud de la sentencia Escamilla en noviembre de 1494, aunque don Alvaro exigió antes de entregarla que se le pagase el importe de unos edificios y de una fortaleza que había construido en este lugar y que él tasaba en 800.000 maravedies ${ }^{158}$.

Además de esta deuda con don Alvaro de Luna, el Il señor de Valdezcaray debía a su madrastra doña Contesina 1.800 .000 maravedíes por el acuerdo económico al que habían llegado en 1491, por lo que el 20 de junio de 1496 los Reyes Católicos le dieron autorización para vender o

155 Todas las cantidades debian ponerse en poder de don lñigo Manrique, obispo de Córdoba, para que se encargase de comprar bienes con los que formar un mayorazgo para doña Contesina y su hijo Bernabé. Villamaderne, 10 de enero de 1491. RAH. Col. Salazar. M-8. Fols. 124-126. Pruebas, págs. $468-470$.

156 Santurde, 11 de enero de 1491. RAH. Col. Salazar. M-8. Fol. 126v.

157 Don Alvaro mientras duraba el pleito intentó vender Escamilla “a alguna o algunas personas poderosas", pero los monarcas informados por don Pedro y su hermanastro Bernabé ordenaron que nadie comprase dicha villa y prohibieron a don Alvaro venderla. Córdoba, 19 de mayo de 1491. A.G. Simancas. Sello. Fol. 15.

158 Escamilla, 12 de febrero de 1496. Archivo Histórico Nacional. Sección de Osuna, legajo $2.071, n^{0} 3$. 
empeñar bienes de su mayorazgo hasta dicha cantidad. Para hacer frente a sus crecientes deudas, fruto tanto de estos acuerdos como de otros que había firmado con los Leiva para lograr el señorío completo de Ezcaray ${ }^{159}$, don Pedro solicitó diversos préstamos al conde de Oñate y a Pedro Suárez de Figueroa, que solo sirvieron para agravar su pésima situación económica. Los condes de Oñate vendieron en 1496 la deuda que el II señor de Ezcaray tenía con ellos al Patriarca de Alejandría Diego Hurtado de Mendoza por 664.540 maravedíes. En agosto de 1497 don Pedro Manrique para librarse de ella y obtener otros ingresos con los que solventar su maltrecha economía, decidió vender Escamilla al citado Patriarca por 2.700.000 maravedíes ${ }^{160}$. La venta, sin embargo, no debió prosperar, porque al año siguiente don Pedro Manrique vendió la villa al Conde de Cifuentes Juan de Silva por 10.000 ducados de oro con la autorización de su mujer y su hijo ${ }^{161}$. El Patriarca de Alejandría, considerándose agraviado,

159 En 1487 don Pedro Manrique se habia comprometido a pagar a Juan de Leiva 6.160.000 maravedies por Ezcaray, Zorraquin y Valgañón, y a vender a este señor Villanueva del Conde, Ventosa y Redecilla del Campo por 4.800.000, en cuenta de la primera cantidad, así como a entregarle su villa de Anguiano. También debia abonarle cierta cantidad por las tercias de Ezcaray. Los monarcas dispuestos a ayudar a don Pedro Manrique, sin duda por el afecto que la Reina Isabel profesaba a su esposa doña Elvira Manuel que servía en palacio, concedieron a ésta en 1488500.000 maravedies para la compra de Ezcaray -Robledo de Chavela, 21 de agosto de 1488. RAH. Col. Salazar. M-45. Fol. $60 \mathrm{v}$ - - y al año siguiente autorizaron a don Pedro a vender bienes de su mayorazgo - Anguiano, Villanueva, Ventosa o Redecilla del Campo y sus maravedíes de juro- para cumplir la concordia con Juan de Leiva, siempre y cuando lo que comprase fuese introducido en el mayorazgo. Después los monarcas cambiaron de opinión, sin que cono conozcamos las causas, pero ante los alegatos de don Pedro Manrique sobre el peligro de que se rompiese la concordia con Juan de Leiva, volvieron a autorizar la venta. 30 de enero de 1489. A.G. Simancas. Sello. Fol. 19. En 1507 Juan de Leiva y don Pedro Manrique confirmaban la concordia de 1487, que habia sido confirmada por los Reyes Católicos en Salamanca el 9 de enero de 1489. Santo Domingo de la Calzada, 22 de abril de 1507. A.G. Simancas. Diversos de Castilla, legajo 40 , fol. 23 .

${ }_{160}$ Además, según constaba en una de las cláusulas del acuerdo, este prelado debia hacerse cargo de la deuda que tenia el señor de Ezcaray con Pedro Suárez de Figueroa, que al parecer llegaba a 1.522.000 maravedies. La esposa de don Pedro Manrique, doña Elvira Laso Manuel, le habia autorizado a realizar dicha venta por un poder que otorgó en Ezcaray el 17 de julio de 1497. AHN. Sección de Osuna, legajo 2.071, $n^{\circ} 5$.

161 Guadalajara, 22 de mayo de 1498. AHN. Sección de Osuna, legajo 2.071, nำ 6. También puede consultarse RAH. Col. Salazar. M-94. Fols 292-293v. Los ducados fueron estimados en 3.750.000 maravedies de la moneda corriente. Guadalajara, 23 de mayo de 1498. AHN. Sección de Osuna. Legajo $2.071, n^{\circ} 7$. Aunque la venta se realizó en 1498 parece que ya desde 1496 don Pedro Manrique andaba en tratos con el Conde de Cifuentes don Juan de Silva para la venta de Escamilla, porque este año el conde autorizaba a su criado Luis de Guzmán, alcalde de Cifuentes, para que pudiese comprar a don Pedro dicha villa en doblas o maravedies, según se tasase. Sevilla, 7 de abril de 1496. AHN. Sección de Osuna, legajo 2.071, $n^{\circ} 4$. Don Pedro Manrique se comprometió a proteger la venta y defenderla de cualquier persona que pretendiese perturbarla, en previsión quizás de que el Patriarca de Alejandria trataria de impugnarla. Valladolid, 30 de junio de 1498. AHN. Sección de Osuna, Legajo 2.071, $n^{\circ} 9$. En nombre del conde tomó posesión de la villa 
inició entonces un pleito contra el conde de Cifuentes y don Pedro Manrique que ganaría en grado de vista y de revista en 1501 y $1506{ }^{162}$.

En el transcurso del enmarañado litigio judicial don Pedro Manrique y su hijo Antonio informaron a los Reyes de la necesidad que habían tenido de vender Escamilla al Conde de Cifuentes. Los soberanos estudiaron el asunto y llegaron a la conclusión de que el trato era útil para la conservación del mayorazgo de estos señores porque les permitiría recuperar Santurde - una vez que solventasen todas las deudas que pesaban sobre ella-, villa que por su ubicación geográfica era mucho más provechosa para el propio mayorazgo que Escamilla. Por ello los monarcas aprobaron la venta el 16 de agosto de $1503^{163}$. Así las cosas el 18 de noviembre de 1507 Pedro Manrique ratificó el acuerdo con el conde de Cifuentes que tomó posesión nuevamente de Escamilla el 20 de mayo de $1508{ }^{164}$.

\section{El señorio de las Amayuelas}

\section{a) El origen del señorio}

El señorío de las Amayuelas surgió en 1440 cuando el Adelantado de León Pedro Manrique decidió en su testamento dejar a su hijo más pequeño Garci Fernández Manrique (i-1496) sus villas de Amayuelas de Arriba y Amayuelas de Abajo - situadas en Palencia ${ }^{165}$-, siete lanzas del rey y 16.616 maravedíes de juro situados en San Cebrián y Támara ${ }^{166}$. Este era el sexto mayorazgo que fundaba el Adelantado con su rico patrimonio.

el 25 de octubre de 1498 Lope de Frías, criado de don Pedro Manrique, por la licencia que éste le dio en Valladolid, el 5 de julio de 1498. AHN. Sección de Osuna. Legajo $2.071 n^{\circ} 10$. En virtud de dicho poder don Lope tomó la villa unos meses más tarde. Ibídem, $n^{0} 17$. Al carecer don Pedro Manrique de autorización real para realizar la venta hubo de establecerse una prórroga en Valladolid el 10 de noviembre de 1498. AHN. Sección de Osuna. Legajo 2.171, ñ 14.

162 La Chancillería de Valladolid ordenó al corregidor de Huete que secuestrase Escamilla hasta que se resolviese el pleito pendiente entre el Patriarca de Alejandría, el Conde de Oñate y Pedro Manrique por las deudas de este último. Al mismo tiempo el Patriarca entablaba otro pleito con el Conde de Ciłuentes sobre la villa de Escamilla. AHN. Sección de Osuna, legajo 2.071, ñ 15 y 17.

163 Los reyes consideraban que las deudas que tenía el señor de Ezcaray eran tantas que su “mayorazgo estava perdido". A.G. Simancas. Cámara de Castilla. Personas, legajo 16.

164 AHN. Sección de Osuna, legajo 2.071, no 17.

165 Estas villas pertenecian a los Manrique desde antiguo. La villa de Amayuelas de Arriba o Amayuelas de Suso, según constaba en el Libro Becerro de las Behetrías, era de la Orden del Santo Sepulcro, de quien al parecer la tenia el V señor de Amusco don Garci Fernández Manrique "por sus dias". La villa de Amayuelas de Abajo, Amayuelas de Yuso, fue solariega de este mismo señor. Ed. cit., tomo I, págs. 216-217.

166 Testamento dado en Valladolid, el 20 de septiembre de 1440. RAH. Salazar. M-2. Fols. 8393. Pruebas, ág. 256-261. 
El primer paso de don Garci al frente de la gestión de su hacienda fue la compra de diversas heredades en las villas de Amayuelas, como las que adquirió en 1459 del Comendador Juan Martínez de Burgos por 33.000 maravedíes ${ }^{167}$. Un año después su pequeño patrimonio sufría un ligero impulso con la concesión que le hizo el rey Enrique IV de 66.607 maravedíes y dos cornados de juro de heredad en los que se incluían los que tenia de su padre ${ }^{168 .}$

En 1463 su sobrino el conde de Treviño, al que le unían grandes lazos afectivos, le hizo donación del lugar de Espinosa, cerca de Anusco ${ }^{169}$, y en 1465 Enrique IV le concedió Préjano, con su jurisdicción alta y baja y sus rentas, lugar que habia sido confiscado a Garci Franco por actuar en su deservicio. Al final esta merced por el derrotero que tomaron los acontecimientos políticos no tuvo efecto ${ }^{170}$, ya que don Garci abandonaría el partido enriqueño y se uniria al del Infante Alfonso ${ }^{171}$.

En 1468 el señor de las Amayuelas compró el lugar de Vecilla, cercano a la villa de Ribas, al Monasterio de Calabazanos, fundación religiosa de la familia Manrique donde se encontraba retirada su madre y habian profesado algunas de sus hermanas. Don Garci adquirió el lugar con todas sus rentas y derechos por 190.000 maravedíes ${ }^{172}$.

La lealtad y servicio de don Garci Fernández Manrique a los Reyes Católicos durante la guerra civil castellana fue premiada en 1479 por Fernando con la concesión de la villa de Xiquena y de la mitad del lugar de Teriaza, bienes confiscados a don Diego López Pacheco, Marqués de Villena ${ }^{173}$.

167 Amayuelas de Suso, 3 de octubre de 1459. Pruebas, pág. 524.

168 Segovia, 20 de noviembre de 1458. A.G. Simanca. Mercedes y Privilegios. Legajo 77. Fol. 45.

169 Don Pedro impuso ciertas condiciones en la donación: Don Garci debia entregar al Conde de Paredes Rodriguo Manrique los 90.000 maravedies por los que le habia empeñado dicho lugar, y tanto él como sus sucesores en caso de querer venderlo deberian ofrecérselo primero a él o a cualquiera de sus sucesores que poseyera la villa de Amusco. Los Molinos, Aldea de la villa de Ocón. 3 de agosto de 1463. Pruebas, págs. 524-525. La estrecha relación entre tio y sobrino se pone de nuevo de manifiesto en 1468, cuando la esposa del conde de Treviño, doña Guiomar de Castro, le renunció 30.000 maravedíes de juro. 29 de abril de 1467. Mercedes y Privilegios, legajo 77 , fol. 45 . A los que sumaria otros 20.000 más que también le renunciaria la mencionada señora tres años después. Carrión, 13 de julio de 1471. Pruebas, pág. 527.

170 Simancas, 23 de septiembre de 1465. Pruebas, pág. 526.

171 Como recomponsa don Alfonso le confirmó los 66.607 maravedies de juro de heredad. Fortilto, 6 de febrero de 1466. A.G. Simancas. Mercedes y Privilegios, legajo 77. Fol. 45.

172 Calabazanos, 13 de abril de 1468. Pruebas, pág. 526-527. Años después entregó este lugar a la viilla de San Cebrián para que los vecinos de ella y sus sucesores los tuviesen en censo perpetuo pagando cada año a él y a sus herederos 170 cargas de pan, mitad trigo y mitad cebada, de la medida de cuatro fanegas la carga, asi como tres docenas de gallinas. Todo ello deberian pagarlo cada año el día de Nuestra señora de septiembre. San Cebrián, 26 de mayo de 1477. Luis SALAZAR Y CASTRO, Casa de Lara, pág. 655.

173 La merced incluía todos los derechos, jurisdicción alta y baja, mero y mixto imperio, así como con los yantares, martiniegas, pechos, escribanias, portazgos, infurciones y la mitad de las 
Desgraciadamente tampoco esta merced llegó a consumarse porque los Reyes tras perdonar a don Diego le devolvieron estas posesiones.

\section{b) Los mayorazgos fundados por el I señor de las Amayuelas Garci Fernández Manrique}

En 1487 don Garci Fernández Manrique fundó un primer mayorazgo para su primogénito Bernaldino Manrique con la condición de que si fallecía sin sucesión masculina o femenina lo heredase su quinto hijo don Iñigo Manrique, ya que los otros pertenecían a Ordenes Militares o eran clérigos ${ }^{174}$. El mayorazgo incluía los siguientes bienes: las villas de las Amayuelas y los lugares de Espinosa de Valdeolmos y Vecilla con su jurisdicción, rentas, derechos, edificios y casas; todos los heredamientos, molinos, sotos, censos y demás bienes que tenía en las villas de San Cebrián, Villamediana y Palacios; los maravedies de juro; las alcabalas y tercias de Espinosa de Valdeolmos; el Cortijo de Bujalance, que se llamaba "Zaragoza", y las Casas que poseía en Palencia y en Amusco.

Los servicios de don Garci Fernández Manrique durante la guerra de Granada fueron premiados por los monarcas con la concesión de diversas mercedes que alcanzaron un valor de 1.070 .000 maravedíes, por lo que según se ha dicho, este caballero fue uno de los más beneficiados en la política de mercedes regias en Granada ${ }^{175}$. Las donaciones fueron esencialmente casas, hornos, molinos, baños, mesones, y diversas fanegas de tierra y aranzadas de viñas en Málaga, Coín, Alozáina y Chilches ${ }^{176}$. Estas mercedes y otras adquisiciones posteriores de don Garci servirian de base para formar un segundo señorío sureño, ya que este señor incrementó sus

pagas y "lievas". Los monarcas ordenaron al concejo de Xiquena que entregase a don Garci el señorio y posesión y la fortaleza, y autorizaron a éste a poner los oficiales. Cáceres, 2 de abril de 1479. RAH. Col. Salazar. M-6. Fols. 234-237.

174 Mayorazgo fundado en Córdoba el 21 de marzo de 1487. RAH. Col. Salazar. M-104. Fols 129v-136. En sus testamento don Garci confirmó este mayorazgo. Testamento otorgado el 20 de marzo de 1494. RAH. Col. Salazar. M-104. Fols. 139-143. Pruebas, págs. 533-538. Ese mismo año don Garci, su esposa y don Bernaldino solicitaron licencia a los monarcas para sacar del mayorazgo el lugar de Espinosa de Valeolmos, las casas de Amusco y el cortijo de Zaragoza situado en Bujalance, licencia que les fue concedida, aunque ignoramos por qué la solicitaron. Medina del Campo, 30 de abril de 1494. A.G. Simancas. Sello. Fol. 9.

175 Miguel Angel Ladero QueSADA, "Mercedes Reales en Granada anteriores al año 1500". Hispania, vol. XXXIX (1969), págs. 41-42.

${ }_{176}$ RAH. Col. Salazar. M-6. Fols. 70, 71, 105 y 106. Pruebas, págs. 532-533. También en A.G. Simancas. Sello. Fol. 12. Para más datos sobre las mercedes de don Garci en el Reino de Granada, véanse, además del artículo ya citado del Profesor Ladero, los trabajos de J.E. LOPEZ DE Coca Castañer, La Tierra de Málaga a fines del siglo XV, Granada, 1977, y de R. Bejarano Pérez, Los Repartimientos de Málaga, Málaga, 1985. También son imprescindibles el libro de J.Ma Ruiz 
propiedades con diversas compras en la ciudad de Málaga, donde era corregidor y alcaide, y en los otros lugares y villas donde tenía posesiones. Don Garci estaba interesado principalmente en aumentar las adquisiciones de medios de producción, muy demandados entonces, como molinos, colmenares, o mesones que reportaban grandes ingresos bien por su explotación, al estar situados en vías importantes, o a través de su arrendamiento ${ }^{177}$.

Con todos los bienes rústicos y urbanos que tenía en las tierras malagueñas don Garci fundó un segundo mayorazgo para su hijo Iñigo Manrique en 1491, gracias a la licencia real concedida el año antes por los Reyes ${ }^{178}$. En el mayorazgo se incluian todas las tierras, viñas, casas y huertas que tenía en Alozáina y en Coín y en la alquería de Chilches, así como los olivares, almendrales y el lagar que poseía en este último sitio. En Málaga le vinculaba por mayorazgo todos los bienes raíces, las casas, los mesones, las huertas, etc. ${ }^{179}$.

En su testamento otorgado en 1494 el I señor de las Amayuelas añadió a este mayorazgo los bienes que había ido comprando en Málaga después de 1491, según dice "de mis propios dineros que yo gané sirviendo a sus altezas...". Todas las posesiones malagueñas fueron la base patrimonial de don Iñigo. Este amplió sus posesiones con las mercedes regias que recibió en 1508 en Frigiliana ${ }^{180}$ y con otras compras que hizo en este mismo lugar y en Nerja, además de con los bienes que aportó al matrimonio su esposa doña Isabel Carrillo. Don Iñigo Manrique $(i-1536)$, sin embargo, no vinculó a su mayorazgo las posesiones de Frigiliana y Nerja, sino que decidió dejárselas por herencia a su segundo hijo, Rodrigo, cuyos sucesores alcanzarian el título de Condes de Frigiliana ${ }^{181}$.

Muerto don Garci en 1496, su sucesor, el I/ señor de las Amayuelas Bernaldino Manrique $(i-1517)$, no incrementó apenas el patrimonio paterno. Corrían tiempos difíciles y don Bernaldino, como noble de pocos recursos, tenía graves problemas para mantener un nivel de vida adecuado a

POVEDANo, Foder y Sociedad..., págs.35-79, y su artículo “Un linaje nobiliario de la élite malagueña: Los Manrique. Las ciudades andaluzas (siglos XIII-XVI). Actas del $V$ Coloquio Internacional de Hiștoria de Andalucia, Málaga, 1991, págs. 444-447.

177 Según se ha dicho, la élite malagueña en general no se contentó con lo que había conseguido en los repartimientos, y por ello inició una amplia politica de compras para redondear sus patrimionios. J.M. Ruiz Povedano, Poder y Sociedad..., págs. 79-80. Una relación de las compras efectuadas por don Garci en el artículo de este mismo autor "Un linaje nobiliario de la élite...", pág. 451.

178 Sevilla, 9 de diciembre de 1490. A.G. Simancas. Sello. Fol. 5.

179 Málaga, 8 de abril de 1491.RAH. Col. Salazar. M-6. Fols. 110-114v. Pruebas, págs.559-562.

180 Diversos heredamientos, viñas, huertas y demás bienes raices de los conversos en Frigiliana. Burgos, 26 de febrero de 1508. RAH. Col. Salazar.M-7.Fols. 15-16.

181 Luis Salazar y Castro, Casa de Lara, tomo II, pág. 725. 
su estatus. A la muerte de su padre los Reyes le confirmaron los 66.607 maravedies y dos cornados de juro de heredad que aquél gozaba en diversos lugares y que había dejado en su testamento a Bernaldino ${ }^{182}$, y pasó a gozar de su mayorazgo. Pronto tuvo que solventar varios problemas sobre términos entre su lugar de Espinosa de Valdeolmos y la villa de Astudillo ${ }^{183}$ y el concejo de Villamediana, a quien su padre había entregado el lugar a censo ${ }^{184}$. Pero quizas los debates más graves fueron con Amusco, villa que tenía derecho a rozar y cortar leña en el término de Espinosa ${ }^{185}$.

Buscando mejorar la gestión de su patrimonio don Bernaldino solicitó licencia en 1505 a los monarcas para vender el lugar de Espinosa que estaba cerca de Astudillo, el cortijo de Zaragoza sito en la población cordobesa de Bujalance y 13.000 maravedies de juro que tenía situados en Ciudad Real. Don Bernaldino explicó a los monarcas que quería vender estos bienes de su mayorazgo para emplear su importe en otros bienes raices situados en Salamanca, ciudad en la que vivia, y en su comarca, donde radicaban los que había heredado de su esposa Isabel Ordóñez ${ }^{186}$.

\section{EL SEÑORIOO DE FUENTEGUINALDO}

\section{a) El origen del señorío}

El origen de este señorío fue el mayorazgo que fundó para don Juan Manrique (¿-1498?) su padre y homónimo el II conde de Castañeda. En

182 Almazán, 4 de julio de 1496. Pruebas, pág. 544. El privilegio fue expedido en Burgos el 27 de octubre de 1496. A.G. Simancas. Mercedes y Privilegios. Legajo 77. Fol. 29.

183 Madrid, 13 de enero de 1498. A.G. Simancas. Sello. Fol. 47.

184 Madrid, 8 de enero de 1498. A.G. Simancas. Sello. Fol. 84. También mantuvo pleitos con el concejo de San Cebrián al que su padre habia entregado a cambio del censo que referíamos más arriba el lugar de Vecilla. En 1507 el concejo y Bernaldino llegaron a un acuerdo en el que se moderaba el censo de 170 cargas de pan a 135 y se aumentaba el número de gallinas en 3 docenas más. Además los moradores se comprometieron a pagar lo que no habían abonado en los años que habia durado la disputa. 13 y 22 de mayo de 1507. Luis SALAZAR Y CASTRO, Casa de Lara, tomo II, pág. 672.

185 En 1501 unos jueces árbitros, Juan de Bretavillo, alcaide de Amusco, y Juan de Castilla, vecino de Salamanca, sentenciaron que los vecinos de Amusco podrían rozar y cortar leña en el término de Espinosa.También confirmaron al concejo de Villamediana el derecho que tenian desde tiempos de Garci Fernández Manrique a rozar este término a cambio de la renta que pagaban a don Bernaldino. Pruebas, pág. 544.

186 Los reyes le dieron autorización para ello el 18 de diciembre de 1505. A.G. Simancas. Sello. Sin fol. En virtud de la licencia real don Bernaldino el 28 de febrero de 1506 vendió a don Diego Fernández de Córdoba y a don Iñigo de Córdoba el cortijo de Zaragoza con sus tierras y dos pares de casas que tenia en la urbe cordobesa por 631.000 maravedíes. Según consta en una escritura dada en Salamanca el 28 de febrero de 1506. Casa de Lara, tomo II, pág. 671. 
dicho mayorazgo este magnate incluyó Fuenteguinaldo con su jurisdicción, rentas y derechos, y los lugares de Revenga, Villarmentero, Villalumbroso y Villatoquite con sus casas fuertes y llanas, la jurisdicción civil y criminal y todos los otros derechos habituales ${ }^{187}$. El primogénito del Conde de Castañeda, el Marqués de Aguilar Gaci Fernández Manrique, mostró pronto su descontento, y como consideró que se habian lesionado sus derechos, trató de recuperar Villatoquite y Villalumbroso. Por ello nada más otorgar su padre la fundación de los dos mayorazgos comenzaron los debates entre ambos hermanos ${ }^{188}$, que decididos a defender lo que creian que les pertenecía por la fuerza de las armas, reunieron numerosas tropas. Los monarcas enviaron a poner "tregua» entre ambos nobles a su alcalde de la Casa y Corte Diego Rodríguez de Baeza, con órdenes de obligarles a derramar las huestes ${ }^{189}$.

En 1486 el Conde de Castañeda otorgó un codicilo donde insistía en que sus dos hijos se contentasen con el reparto de bienes que había hecho en su testamento, estableciendo que si alguno de ellos no lo cumpliera fuese penado con 10.000 doblas de oro ${ }^{190}$. Un año después en el Monasterio de Santa Clara de Aguilar de Campoo volvía a otorgar otro codicilo en el que suplicaba a los reyes que hiciesen cumplir a sus hijos sus disposiciones testamentarias, especialmente que el Marqués, su hijo mayor, entregase a su hermano el lugar y la fortaleza de Villalumbroso ${ }^{191 .}$

Todo fue en vano porque en 1493 ambos hermanos, ya sin el freno de su padre, que fallecería ese año, reanudaron sus hostilidades con mayor fuerza. Don Garci Fernández Manrique trató de convencer a los reyes de que él poseía legítimamente los lugares de Villalumbroso y Villatoquite, y acusó a su hermano de entrar en ellos con ugente armada de pie e de cavallo", de encastillar sus iglesias, y de confiscar una casa a un tal Alonso Ruiz en Villatoquite donde "fiso cuevas e baluartes e otras defensyones..." 192. Don Juan Manrique por su parte, sabiendo que don Garci era mucho más poderoso, demandó lo antes que pudo una carta de

\footnotetext{
187 Mayorazgo fundado en Piña, el 26 de febrero de 1484. RAH. Col. Salazar. M-123. Fols. 84v-93. Pruebas, págs. 132-135.

${ }_{138}$ En los primeros altercados pelearon principalmente por la villa de Piña, aunque desconocemos las razones, ya que esta villa pertenecia al Marqués de Aguilar.

189 Valiadolid, 19 de septiembre de 1485. A.G. Simancas. Sello. Fol. 118.

190 Revenga, 27 de febrero de 1486. Pruebas, pág. 135.

191 Santa Clara de Aguilar de Campoo, 11 de noviembre de 1487. Pruebas, pág. 136.

192 Los soberanos ordenaron a don Juan Manrique derribar todo lo que hubiese construido, derramar las tropas y desencastillar las iglesias bajo amenazas de "...la pena de muerte e perdimiento de todos sus bienes". Valladolid, 5 de julio de 1493. A.G. Simancas.Sello. Fol. 27.
} 
seguro y amparo a los reyes, quienes se la concedieron en agosto de $1493^{193}$.

El litigio entre ambos hermanos se mantuvo firme a lo largo de 1494 y $1495^{194}$, y en su transcurso, como era habitual, hubo de todo: reyertas armadas, amenazas y acusaciones de falsificación de documentos ${ }^{195}$. Finalmente en 1497 don Juan Manrique y su hijo Fabrique recibían autorización de los Reyes para vender el lugar de Villalumbroso al Marqués de Aguilar como vía para concluir los pleitos entre ambas familias, pero los señores de Fuenteguinaldo conservaron Villatoquite ${ }^{196}$.

\section{b) La desmembración del señorío}

Poco después de resolverse el pleito con los Marqueses de Aguilar, falleció don Juan Manrique y le sucedió su hijo Fadrique Manrique ( $i$ 1520), conocido en la época como Mariscal de Zamora. El joven heredaba un pequeño señorio, en el que la villa más importante era Fuenteguinaldo, población donde durante años había intentado su padre construir una fortaleza sin éxito por la oposición de los vecinos de Ciudad Rodrigo ${ }^{197}$. Don

193 En su súplica a los monarcas don Juan había dado también su particular interpretación de los acontecimientos, haciendo recaer toda la culpa en su hermano el Marqués de Aguilar, al que acusaba de haber amenazado a sus escuderos y criados. Don Juan mostraba su temor de que tales amenazas bien podian hacerse realidad y hacia hincapié en que su único deseo era servirles fielmente sin responder a tales provocaciones. Valladolid, 27 de agosto de 1493. A.G. Simancas.Sello. Fol. 252.

${ }_{194}$ Los reyes dieron diversas comisiones a varios de sus oficiales para que tomasen declaraciones a cuantos testigos pudiesen, con el fin de dilucidar los derechos de las respectivas partes en conflicto. Valladolid, 27 de febrero de 1494. A.G. Simancas. Sello. Fol. 295. Medina del Campo, 15 de abril de 1494.Ibidem. Fol. 132. Segovia, 30 de junio de 1494. Ibídem. Fol. 271 . Madrid, 11 y 19 de diciembre de 1494. Ibídem. Fol. 230 y 247, respectivamente. Madrid, 20 de febrero de 1495. A.G.Simancas. Sello. Fol. 435. Madrid, 21 de febrero de 1495, ibidem, fol. 427 y 320 . Madrid, 31 de marzo de 1495. Ibidem, fol. 210. Madrid, 11 de abril de 1495. Ibiem. Fol. 267. Burgos, 8 de agosto de 1495. Ibidem. Fol. 57.

195 Don Juan Manrique presentó a los monarcas un codicilo de su padre, otorgado ante el escribano Juan de Santillana, que el Marqués de Aguilar dijo que era falso, por to que los reyes pidieron al primero que presentase en el Consejo la escritura original. Madrid, 23 de diciembre de 1494. A.G. Simancas. Sello. Fol. 246.

196 Burgos, 3 de mayo de 1497. A.G. Simancas.Sello. Fol. 6.Dos años después los monarcas autorizaban a don Fadrique a invertir lo obtenido por la venta de Villalumbroso en otras heredades para incorporarlas a su mayorazgo. Madrid, 14 de mayo de 1499. A.G. Simancas.Sello. Fol. 6.

197 Los vecinos mostraron su total desacuerdo con la construcción, presentaron sus quejas y argumentos de lo pernicioso que sería la edificación de la misma, sobre todo en tiempo de revueltas, y lograron que los monarcas escuchasen su parecer. Por este motivo los Reyes Católicos ordenaron a don Juan que dejase de construir la fortaleza -Córdoba, 10 de junio de 1486. A.G. Simancas. Sello. Fol. 97-, aunque si le dieron autorización para edificar una casa llana tras las protestas de don Juan Manrique, que habia dicho a los reyes que lo único que él pretendia era 
Fadrique, asentado desde su matrimonio en la ciudad de Zamora donde era regidor, no debía de gozar de un estatus económico boyante porque en 1504 recibió autorización real para vender su lugar de Villatoquite ${ }^{198}$, y en 1506 para vender las casas que tenía en la ciudad de Zamora y la villa de Fuenteguinaldo ${ }^{199}$. Ésta fue adquirida por don Garcia y don Pedro de Toledo, Marqueses de Villafranca, a cambio de 173.000 maravedíes de juro que tenían en Burgos ${ }^{200}$.

Con estas ventas don Fadrique dilapidó casi todo el patrimonio familiar. Con el paso del tiempo su pésima situación económica se fue agravando, porque primero se apropió de la dote y arras de su madre ${ }^{201}$, y después en 1518 vendió a su cuñado Alonso Niño un juro de 26.873 maravedíes de su mayorazgo que tenía en las alcabalas de Burgos. En la licencia real para realizar dicha venta se señalaba que don Fadrique tenía ciertas deudas con don Alonso Niño, con el Comendador del Monasterio de las Huelgas de Burgos, donde tenia dos hijas que habian profesado como monjas, y con ciertos mercaderes, y se añadía que no disponía de dinero ni de bienes para pagarlas ${ }^{202}$. Estas deudas dan una idea aproximada de cuál era el estado económico de don Fadrique, y nos ponen sobre la pista de las dificultades de los pequeños nobles para mantener un ritmo de vida cada vez más costoso.

\section{OTROS SEÑORIOS}

Para terminar queremos hacer referencia a tres pequeños señoríos, cuyo futuro se vió truncado por la falta de heredero varón de sus titulares.

construir una «...casa llana de aposentamiento para en quel pueda bivir e morar segund su estado e condición...". En la licencia para construir la citada casa los monarcas ordenaron a don Juan acatar las siguientes condiciones: que no pudiese hacer en ella "tronera ni saetera ni baluarte ni cava ni barrera, ni torre ni almenas e que la pared de la dicha casa no pueda ser mas ancha de tres pies e medio...". Salamanca, 14 de diciembre de 1486. A.G. Simancas. Sello. Fol. 37. A pesar de las órdenes regias don Juan continuó construyendo su fortaleza, por lo que los monarcas enviaron al corregidor de Ciudad Rodrigo para que inspeccionase las obras y derribase todo aquello que no se ajustase a lo por ellos ordenado. Real sobre Málaga, 5 de julio de 1487. A.G.Simancas. Sello. Fol. S4. Valladolid, 25 de septiembre de 1498. A.G. Simancas. Sello. Fol. 201.

19822 de octubre de 1504. A.G. Simancas. Sello. Sin foliar.

19930 de marzo de 1506. A.G. Simancas. Sello. Sin foliar.

200 La cesión fue realizada el 13 de abril de 1506, en el Monasterio de San Leonardo, extramuros de la villa de Alba de Tormes. A.G. Simancas. Diversos de Castilla. Legajo 40, $n^{\circ} 29$.

201 Según ella misma refiere en una escritura dada en Nájera el 12 de diciembre de 1512. A.G. Simancas. Cámara de Castilla. Personas. Legajo 16.

202 Licencia real dada en Valladolid el 23 de febrero de 1518. A.G. Simancas. Diversos de Castilla. Legajo $40, n^{\circ} 6$ 


\section{a) El señorio del Adelantado de Castilla Gómez Manrique}

El Adelantado de Castilla don Gómez Manrique (1356-1411) 203 fue hijo bastardo del VI señor de Amusco don Pedro Manrique. Su condición de ilegítimo le impidió suceder a su padre en sus señoríos, pero tampoco lo dejó totalmente desamparado y relegado en su linaje, porque su tío el Arzobispo de Santiago Juan García Manrique le incluyó en el derecho sucesorio del mayorazgo de Amusco. Además don Gómez heredó algunas posesiones de su familia, como el castillo de Malvecino. A lo largo de su vida el Adelantado luchó mucho para labrarse una posición social y política. Gracias a sus esfuerzos consiguió reunir un considerable patrimonio ${ }^{204}$-aunque no tenía comparación con el de otros parientes más poderosos 205_, que se hallaba disperso por las Merindades de Castilla la Vieja, especialmente en Tierra de Campos y Burgos, como los del resto de los miembros del linaje.

La adquisición más importante que hizo Gómez Manrique fue Frómista. En 1389 compró por 1.500 doblas de oro la mitad de la villa a Sancho Fernández de Tovar, y poco después la otra parte a su sobrina doña Mencía por 2.500 doblas de oro ${ }^{206}$. El Adelantado de Castilla tenia también las villas de Villalba de Losa y Santa Gadea con sus aldeas, términos, pechos y derechos, aunque desconocemos por qué vías las adquirió. Además poseía el castillo de Malvecino con unas casas y unas tierras, heredado posiblemente de su tío Gómez Manrique fallecido sin hijos, y el lugar de La Piedra con un suelo de castillo y los derechos de infurción y martiniega ${ }^{207}$.

203 Una semblanza sobre este personaje nos la ofrece Fernán PÉREZ DE GUZMAN en sus Generaciones y Semblanzas, cap. XV, pág. 706.

204 Del patrimonio de don Gómez Manrique se ocupó en su momento con gran detalle Alfonso Franco en uLa fortuna del Adelantado Mayor de Castilla Gómez Manrique", Ifigea, II, Córdoba, 1985,págs. 107-123.

205 Alfonso Franco al estudiar el patrimonio del Adelantado puso de manifiesto que se trataba de una fortuna nobiliaria mediana, al compararla con la que poseian otros nobles de la época. "La fortuna...", pág. 115.

206 En 1374 Enrique II concedió Frómista al Almirante Fernán Sánchez de Tovar en recompensa por las 6.000 doblas de oro que le pertenecian por el rescate del caudillo portugués Alfonso Domínguez, a quien había hecho prisionero en la pasada guerra con Portugal. Privilegio de Enrique Il dado el 20 de agosto, era de 1412, año de 1374. Tanto este documento como la confirmación del rey Juan I se hallan insertos en una escritura dada en Burgos el 30 de octubre de 1496. A.G. Simancas. Sello. Fol. 2. A la muerte de Fernán Sánchez heredaron Frómista sus hijas Elvira y Mencia. La primera vendió a su tío Sancho Fernández de Tovar la mitad que le pertenecía por 20.000 maravedies junto con el lugar de Castro Ponce. Mencia y su tío conservaron Frómista hasta 1389. A. Franco, “La fortuna...", pág. 109, notas 11, 12, 13.

207 Este lugar lo compró a Luis de Probano a quien todavía debía 11.000 maravedies cuando otorgó su testamento, según el mismo lo refiere. Testamento dado en Córdoba, 21 de abril de 1410. AHN. Sección de Clero, legajo $n^{\circ} 1053$. 
Su esposa doña Sancha de Rojas aportaría al matrimonio el lugar de Rojas con ciertas posesiones, el usufructo y señorio del lugar de Arcos durante su vida y otros pequeños bienes ${ }^{208}$. Ya casados, don Gómez y su mujer adquirieron el lugar de Requena de Campos en Palencia, que según Luis Salazar y Castro, le vendió al Adelantado Juan de Padilla, hijo de Lope Fernández de Padilla, señor de Serón ${ }^{209}$. También era lugar solariego suyo Villasán, donde tenia una casa fuerte, un monte y ciertas heredades de pan llevar. Por último don Gómez poseía diversas heredades, casas, viñas, molinos, solares y huertas en numerosos lugares, fruto de sucesivas compras ${ }^{210}$.

En su testamento Gómez Manrique fundó un mayorazgo para el hijo que esperaba su esposa, en caso, claro está, de ser varón, con la villa de Frómista, Santa Gadea y Villalba de Losa; todo lo que le pertenecía en Sotopalacios y Requena; todas las heredades que tenía en el término de Frómista y de Población; los vasallos que poseía en Piña de las Nueve Villas, el castillo de Ubierna, el de Malvecino, y todos los otros castillos, casas y heredades que gozaba en el Valle del Río Ubierna, sus posesiones de Valdevielso y 10.000 maravedíes de juro de heredad ${ }^{211}$. Sus restantes bienes se los dejaba a sus hijas. En el caso de no tener ningún hijo varón don Gómez establecia que heredase Frómista su primogénita doña María, con los 10.000 maravedies de juro, los bienes de Requena de Campos, las heredades de Frómista y Población, y los vasallos de Piña y Santillana, así como las casas y heredades que tenía en Osorno del Tonrradero. El resto establecía que se lo repartiesen sus otras hijas, aunque su madre no entregaría nada a ninguna hasta que contrajeran matrimonio.

Dos años después de fallecer el Adelantado, al no haber nacido ningún hijo varón ${ }^{212}$, se reaiizó un inventario ${ }^{213}$ de sus bienes con el fin de proceder

208 Alfonso Franco, “La fortuna...", pág. 111.

209 Asi se dice, según recoge el mencionado autor, en el testamento de Juan Rodriguez de Rojas, su bisnieto. Pruebas, pág. 75. Casa de Lara, tomo I, pág. 420.

210 Véase para más detalle A. Franco, "La fortuna...",págs. 110-112. La mayoría de las compras don Gómez las hizo en sus propias villas o en aquellos lugares que habian estado vinculados de una forma $u$ otra con la familia Manrique bien por ser de behetría, solariegos suyos o simplemente por haber gozado en ellos de naturaleza. Por citar algunos ejemplos: Santa Gadea, Sotopalacios, Celadilla, Vivar del Cid., Ubierna, Arnillas de Candemuño, Robredo-Sobresierra, Robredo de Treviño, Teirados, Marquillos, Población de Valdivielso, Piña de Campos o Santillana de Campos.

211 Don Gómez tenía 40.000 maravedies de juro. A.G. Simancas. Mercedes y Privilegios.Legajo 1, fol. 794

${ }^{212}$ Doña Sancha en su testamento otorgado en 1437 dejaba un legado de mil maravedies para el ama de don Enrique. Puede que este fuera el hijo póstumo del Adelantado y que falleciese siendo niño. Burgos, 4 de agosto de 1437. AHN. Sección de Clero. Legajo № 1.053.

213 Inventario de bienes de Gómez Manrique realizado por mandato real en Valladolid, el 10 de mayo de 1413. El inventario se encuentra en el cajón 69 del Archivo Ducal de Frías. Alfonso Franco, “La fortuna...", pág. 108. 
al reparto de los mismos entre sus herederas ${ }^{214}$. En 1437 su esposa doña Sancha otorgaba testamento en Burgos y dejaba todos sus bienes a sus hijas, pero mejoraba a una de ellas, doña Mencía, con Villeveta ${ }^{215}$, lugar que había comprado a María de Cisneros, señora de Camporredondo, en $1413^{216}$. También le confirmaba la donación que le habia hecho de Santa Gadea ${ }^{217}$. En suma, a la muerte del Adelantado Gómez Manrique y de su esposa, toda su hacienda reunida tenazmente durante años se desintegró por la falta de un sucesor varón que la mantuviese unida.

\section{b) El señorío del Corregidor deToledo don Gómez Manrique}

También tenemos que mencionar el señorio del célebre poeta y Corregidor de Toledo Gómez Manrique (¿-1490), hijo del conocido Adelantado de León Pedro Manrique, que sólo le dejo por mayorazgo siete lanzas del rey, 9.500 maravedíes de juro y ciertos bienes de su esposa en León. A pesar de su dilatada y renombrada carrera política, don Gómez no logró reunir un importante patrimonio señorial, porque su continua posición rebelde contra Juan II y Enrique IV le privaron de posibles mercedes regias. El efímero "reinado" del Infante Alfonso, del que fue incansable seguidor, no le aportó más beneficio que el desempeño del corregimiento de Avila y la exigua suma de 5.000 maravedíes anuales de merced para su mantenimiento ${ }^{218}$.

Tampoco los Reyes Católicos se mostraron muy espléndidos con su fiel servidor en lo que a concesión de señoríos se refiere ${ }^{219}$, aunque sí parece

214 De los datos que aporta Alfonso Franco se deduce que no se cumplió fielmente la voluntad expresada por Don Gómez en su testamento, pues señala que a doña Sancha, como viuda le correspondió la mitad de todos los bienes gananciales, junto con su patrimonio personal, y que el resto se dividió en partes iguales entre sus hijas,cuando don Gómez habia separado ciertos bienes para su hija Maria. Alfonso Franco, "La fortuna... ", págs. 114-115.

215 Doña Sancha dice asi: «E por quanto mi fija Donna Mencia me a fecho singulares e sennalados servi;ios, e porque le soy mucho obligada, e le sea dada mejoria de la tercia parte de mis bienes todos...; la qual mejoría es mi voluntad que la aya en Villoveta; Burgos, 4 de agosto de 1437. AHN. Sección de Clero. Legajo n 1.053.

216 Lo habia adquirido por mil florines del cuño de Aragón con todos sus pechos, derechos y jurisdcción. Valladolid, 23 de mayo de 1413. RAH. Col. Salazar.M-45. Fol. 117-117v.

217 Estas cláusulas testamentarias dieron lugar a diversos pleitos entre las heredades como se deduce de las sucesivas sentencias judiciales, que pueden consultarse en RAH. Col. Salazar. M-51. Fols. 172 a 174, y en A.G. Simancas. Mercedes y Privilegios. Legajo 10. Fol. 148.

218 A.G. Simancas. Quitaciones de Corte. Legajo 3. Fols. 325-326. Su esposa, sin embargo, si resultó algo más agraciada por este "monarca", ya que le hizo merced el 20 de abril de 1466 de 43.000 maravedies de juro de heredad, y el dia 28 del mismo mes y año de 60.000 maravedies para ella y sus sucesores. A.G. Simancas. Mercedes y Privilegios. Legajo 82. Folio 14. Esto nos induce a pensar que quizás hubiera hecho otras mercedes a don Gómez, pero que no haya noticias.

219 Tan solo le otorgaron algunas mercedes monetarias: 70.000 maravedies de juro en las alcabalas de la villa de Aranda y 20.000 en el resto de sus lugares; una merced conjunta a él y su 
que Don Gómez gozó de su efecto y confianza, porque le tuvieron incluso por consejero ${ }^{220}$. La merced más importante que le hicieron los monarcas fue confirmarle la posesión de la villa de Cordovilla en 1489. Gómez Manrique y doña Juana de Mendoza, su mujer, habían protegido a los vecinos y moradores de este lugar cercano a Torquemada en tiempo del Rey Enrique IV, del Conde de Santa Marta y de otros grandes señores. En agradecimiento los vecinos, como eran de behetría, se entregaron por vasallos solariegos a don Gómez, y los soberanos le confirmaron el señorío ${ }^{221}$.

En 1487 los Reyes Católicos dieron licencia a don Gómez Manrique, entonces Corregidor de Toledo, para fundar mayorazgo en su nieta doña Ana Manrique ${ }^{222}$, ya que su único hijo varón, Luis Manrique, padre de la joven, había fallecido. En el citado mayorazgo el corregidor incluyó las villas de Belbimbre y Villazopeque con su fortaleza, y los lugares de Cordovilla y Matanza ${ }^{223}$, poblaciones situadas en la actual provincia de Burgos. En su testamento don Gómez añadió al mayorazgo otros bienes muebles, 20.000 maravedíes de juro en Cordovilla, la fortaleza de este lugar y todo lo que compró alli a Pedro de Cartagena, así como 70.000maravedíes más de juro en Aranda de Duero ${ }^{224}$.

\section{c) El señorio de Fadrique Manrique}

Otro señorío que se vio truncado por falta de heredero varón fue el de don Fadrique Manrique, señor de Baños (¿-1477). Su punto de partida fueron los bienes que le dejó su padre - el tantas veces citado Adelantado de León Pedro Manrique- en su testamento otorgado en 1440: los lugares de Hito, Baños y Quintanilla, las Aceñas de Cigondo, 7 lanzas del rey

mujer en 1489 de 150.000 maravedies de por vida en las alcabalas de Toledo y 106.000 maravedies más en 1490 A.G. Simancas. Mercedes y Privilegios. Legajo 77. Fols. 50, 51 y 52.

220 A.G. Simancas. Quitaciones de Corte. Legajo 21. En 1477 y en 1479 se le libraban de ración y quitación por consejero de sus altezas 30.000 maravedies.

221 A.G. Simancas. Sello. Valladolid, 4 de febrero de 1489. Fol. 2. Los monarcas poco después del fallecimiento de don Gómez confirmaron nuevamente a doña Juana de Mendoza la posesión del lugar de Cordovilla. Sevilla, 7 de febrero de 1491. A.G. Simancas.Sello. Fol. 176.

222 Real de Málaga, 22 de julio de 1487. Pruebas, págs. 494 y ss.

223 Bienes cuya procedencia, excepto la de Cordovilla, ignoramos. En 1431 Villazopeque y Belbimbre pertenecian a doña Juana de Mendoza. Pascual MARTinez SoPEnA, El estado señorial de Medina de Rioseco bajo el Almirante Alonso Enriquez, (1389-1430), Valladolid, 1977, pág. 78. Doña Juana fue madre del Adelantado de León Pedro Manrique y abuela, por tanto, de don Gómez Manrique, por io que estos lugares bien pudo heredarlos de esta señora.

224 El testamento original con las últimas doce tineas autógrafas se conserva en el Archivo de los Duques de Medinaceli, legajo 237, n 71. Un traslado puede consultarse en AHN. Sección de Clero, legajo 5328. Lo publicó Luis SaLAzAR y CASTro en Pruebas, págs. 496 y ss. 
y 9.500 maravedies de juro anuales ${ }^{225}$. El mayor empuje a esta pequeña hacienda vino de la mano del matrimonio de don Fadrique con doña Elvira de Figueroa - cuya dote incluía algunos lugares como Sotosgudo, Salazar y Palazuelos-, ya que su trayectoria política no le proporcionó mercedes sustanciosas.

A lo largo de su carrera don Fadrique sólo logró incrementar sus bienes lo suficiente para reunir un mediano patrimonio, como correspondía a su categoría de segundón. La merced más importante que recibió fue la que le hizo el Infante Alfonso en 1466 en la que se incluian Mengibar, Cacelilla,Torre del Campo y Fuente del Rey, con sus castillos y términos, lugares de la jurisdicción de Jaén, ciudad que habia sido privada de ellos por seguir el partido del rey Enrique IV ${ }^{226}$. Sin embargo, don Fadrique por las diversas circunstancias políticas se vio obligado a devolver estos lugares, aunque fue recompensado con el cargo de Escribano de las Rentas (alcabalas, tercias y almojarifazgos) de la ciudad de Córdoba y su término, con los derechos de 10 maravedies al millar y los otros salarios y derechos al oficio anexos, con las Salinas de la citada ciudad y unas casas en la misma que se llamaban de las «Camas altas» 227.

Por compra a los herederos de su hermano don Rodrigo Manrique, conde de Paredes, el señor de Hito adquirió también los lugares de Albalá, Santillán, Ralea y Vega de doña Olimpia en la Merindad de Saldaña ${ }^{228}$, bienes que habian sido de la madre de los mismos Mencía de Figueroa. Aparte don Fadrique compró diversos bienes urbanos y rústicos en la ciudad de Écija y en Córdoba, y como el resto de la nobleza y según era habitual en la época gozó de diversas cantidades de maravedíes de juro ${ }^{229}$.

A su muerte en $1477{ }^{230}$ su patrimonio se repartió entre sus hijas. La mayor doña Elvira heredó el mayorazgo, que estaba formado por los bienes que el Adelantado de León don Pedro Manrique había dejado vinculados a

225 Valladolid, 20 de septiembre de 1440. RAH. Col. Salazar. M-2.Fols. 83-93. Pruebas, pág. 256-261.

276 Arévalo, 20 de mayo de 1466. A.G. Simancas. Mercedes y Privilegios, legajo 10,fol. 151.

227 Ecija, 7 de julio de 1469. A.G. Simancas. Mercedes y Privilegios, legajo 77, fol. 41 Confirmado por los Reyes Católicos en Segovia, el 11 de septiembre de 1476.

228 Luis Salazar y Castro, Casa de Lara, tomo II, pág. 588.

229 En concreto: 18.000 maravedies en ciertos lugares suyos, otros 50.000 en Ecija y Córdoba y 43.000 que recibia de salario por tenencia de los alcázares de Ecija. Además tuvo otros 103.000 maravedies en Ecija que dio en dote a su hija doña Francisca para su matrimonio con don Luis Portocarrero. A.G. Simancas. Mercedes y Privilegios. Legajo 77, fol. 41.

${ }_{230}$ Según José Manuel CaLderón ORTEGA, «Pugnas nobiliarias para el control de las dignidades de las órdenes militares en la Castilla bajomedieval: El Caso de la Encomienda de Azuaga (1465-1478)". Espacio, Tiempo y Forma, Serie III, nº 4, (1989), pág. 113. 
don Fadrique. Doña Francisca recibió las propiedades de Andalucia, que eran fundamentalmente diversos bienes rústicos y urbanos en Ecija. En cuanto a las otras dos hijas, en 1488 su madre Doña Beatriz de Figueroa procedió a repartir los bienes que quedaban de su marido y suyos entre ellas, con el fin de que los llevaran como dote para sus respectivos matrimonios ${ }^{231}$.

\section{CONCLUSIONES}

Los señoríos de los Manrique en general se situaron en tierras de Palencia, Burgos, Asturias de Santillana y La Rioja, por tanto en Castilla la Vieja. En torno a este núcleo geográfico estuvieron las principales posesiones de la familia, en una área de accidentado relieve no demasiado buena para el cultivo, en tierras, de escaso rendimiento agrícola dedicadas más bien a la producción ganadera, o a otras actividades secundarias. Los esfuerzos por lograr consolidar señorios en áreas geográficas más meridionales tuvieron escaso éxito, si exceptuamos el pequeño señorio de Frigiliana, que se creó gracias a las mercedes conseguidas durante la guerra de Granada por el señor de las Amayuelas Garci Fernández Manrique, y el de los Condes de Paredes en las tierras alcaraceñas, aunque estos señores fracasaron en su intento de crear un estado señorial más fuerte en esta zona, como fue durante largo tiempo su deseo.

El principal núcleo patrimonial del linaje procedia en su mayoria de fines del siglo XIV, gracias a las generosas mercedes de Enrique II y Juan $I$, y del reinado de Juan $I I$ en el $X V$. Los reinados de Enrique IV y los Reyes Católicos destacaron por el notable frenazo que sufrió el proceso de incremento de los patrimonios, al detenerse la concesión regia de nuevos señorios a la estirpe. En el caso de Enrique IV resulta comprensible si tenemos en cuenta las tensas relaciones que mantuvo el linaje en general con este monarca, por lo que, salvo alguna excepción, como la concesión de la ciudad de Nájera al conde de Treviño, las pocas mercedes de esta etapa son de carácter monetario, como juros. Los Reyes Católicos, como es bien sabido, moderaron claramente la concesión de señoríos a la nobleza, y así se hace evidente en el caso de los Manrique, quienes a pesar

\footnotetext{
231 Dichos bienes debian ser repartidos a partes iguales entre doña Maria Manrique, mujer de don Gonzálo Fernández de Córdoba, y doña Leonor, esposa de don Pedro Carrillo. Palma del Rio, 29 de marzo de 1488. RAH. Col. Salazar. M-6. Fols. 53-55. La parte que recibió María se tasó en dos millones de maravedies, según consta en la carta otorgada por don Gonzalo Fernández de Córdoba en la que se refiere que los bienes que componían la dote de su esposa ascendían a dicha cantidad. Palma del Río, 14 de febrero de 1489. AHN. Sección de Osuna, legajo 1.780, nº 2.
} 
de su incondicional adhesión a su causa apenas recibieron recompensas de este tipo. Por ello salvo las contadas mercedes que algunos miembros del linaje consiguieron durante la conquista de Granada, y algún que otro pequeño favor real, como la confirmación de Cordovilla a Gómez Manrique, por citar algunos ejemplos, el resto no fueron sino mercedes de juro o vitalicias de diferente alcance y valor.

El anquilosamiento de los señoríos de los Manrique que se perfila desde la segunda mitad del siglo XV, se hace más evidente después de la llegada al trono de Isabel y Fernando. A la escasa inclinación de los monarcas a conceder nuevas posesiones a los nobles, se une, una vez terminada la guerra civil y concluida la conquista de Granada, la apertura en Castilla de un período de paz que deja a la nobleza sin dos de sus vías esenciales para conseguir nuevos dominios señoriales y otras gracias regias: la lucha política y la guerra. Es por eso que en los últimos años del siglo XV y los primeros del XVI los señorios de los Manrique, especialmente los más importantes, crecen poco y cuando lo hacen es gracias a compras, donaciones de parientes o herencias. La estabilidad que se apodera de algunos señoríos y el lento desarrollo de otros se manifiesta en que individuos como el Conde de Treviño, por ejemplo, mostraran una especial cautela a la hora de dividir sus patrimonios y fundar nuevos mayorazgos. Así este magnate prefirió dejar todo su estado a su primogénito aun a riesgo de dejar a su otro hijo en una situación económica crítica. Caso extremo es el del Conde de Paredes, que apenas si pudo dejar a su sucesor lo que él había heredado de su padre.

Sin embargo, en la segunda mitad del siglo XV fueron los pequeños señoríos, que tanto proliferan en esos años coincidiendo con el propio crecimiento del linaje Manrique, los que llevaron la peor parte. Nacidos normalmente de segundos mayorazgos, formados casi siempre con unos pocos bienes, tuvieron que enfrentarse con el mismo problema que sus "hermanos mayores", su incapacidad para crecer y consolidarse, agravada en este caso por la condición secundaria de sus titulares, hombres muchos de ellos de escaso protagonismo social y político, que tendrían por tanto más dificultades para acceder a las tan necesarias mercedes regias. A este inconveniente se sumó el que algunos de estos individuos carecieran de la habilidad necesaria para gestionar sus señorios adecuadamente y mantenerlos a flote, como sucedió con el señorio de Valdezcaray o con el de Fuenteguinaldo, este último desmembrado por las continuas ventas. Otros pequeños señoríos del linaje Manrique se desintegraron simplemente por falta de un sucesor varón que continuara al frente de los mismos y los mantuviera unidos. 


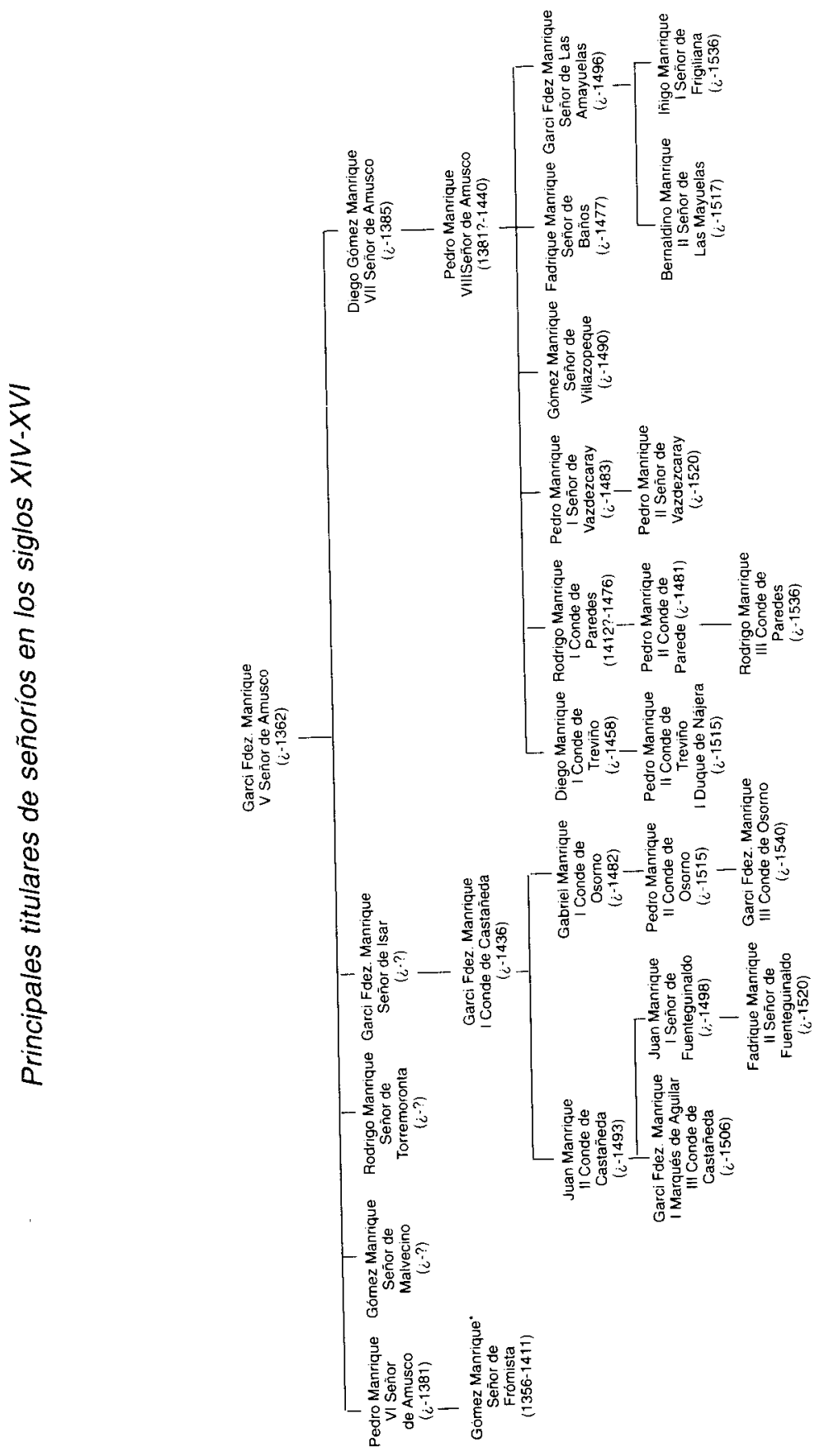

